\title{
Steroidal Glycoalkaloids and Molluscicidal Activity of Solanum asperum Rich. Fruits
}

\author{
Tania M. S. Silva, ${ }^{* a}$ Celso A. Camara, ${ }^{b}$ Kristerson R. L. Freire, ${ }^{c}$ Thiago G. da Silva, ${ }^{c}$ \\ Maria de F. Agrac and Jnanabrata Bhattacharyya ${ }^{c}$
}

${ }^{a}$ Núcleo Complexo Produtivo de Saúde, Instituto Multidisciplinar em Saúde, Campus Avançado Anísio Teixeira, Avenida Olívia Flores, 3000, Candeias, 45055-090 Vitória da Conquista-BA, Brazil

${ }^{b}$ Departamento de Química, Universidade Federal Rural de Pernambuco, R. Dom Manoel de Medeiros, s/n, Dois Irmãos, 52171-900 Recife-PE, Brazil

${ }^{c}$ Laboratório de Tecnologia Farmacêutica, Universidade Federal da Paraíba, CP 5009, 58051-970 João Pessoa-PB, Brazil

\begin{abstract}
O fracionamento bio-monitorado do extrato alcaloídico dos frutos verdes de Solanum asperum forneceu um novo alcalóide esteroidal, denominado solanandaina, juntamente com a solasonina e a solamargina. Tanto o extrato alcaloídico como os glicoalcalóides isolados apresentaram potente atividade moluscicida.
\end{abstract}

Bioassay-guided fractionation of the alkaloidal extract of the green fruits of Solanum asperum afforded a new compound, solanandaine along with solasonine and solamargine. The total crude alkaloids as well as the isolated pure alkaloids exhibited significant molluscicidal activity.

Keywords: Solanum asperum, glycoalkaloid, solanandaine, solasonine, solamargine, molluscicidal

\section{Introduction}

Solanum L. (Solanaceae) is distributed mainly throughout the tropical and subtropical regions of the world and is the largest and most complex genus of the family Solanaceae. In Brazil, Solanum is represented by about 350 species. ${ }^{1}$ In this region, many species of Solanum are widely used in popular medicine and are commonly known as 'yubeba', the word derived from Tupi Guarani that refers to the prickles found on the stems of several of the species. ${ }^{1}$ Some common and wide-spread Solanum species of Brazil had shown ${ }^{2,3}$ considerable molluscicidal activity demonstrated by several members of the genus investigated earlier. ${ }^{4,5}$ Thus, we have been studying various species of Solanum growing in our country ${ }^{3,6-10}$ with the expectation that the extracts of plants of this genus might be useful in the control of Biomphalaria glabrata, the intermediate host of Schistosoma mansoni, the parasite that causes human schistosomiasis in Brazil. In our previous bioassays, the crude $\mathrm{MeOH}$ extract of the unripe fruits of $S$. asperum

*e-mail: sarmento@pesquisador.cnpq.br
Rich showed ${ }^{3,11}$ activity in studies with Artemia salina $\left(\mathrm{LC}_{50}=420.5 \mu \mathrm{g} \mathrm{mL}^{-1}\right)$ and Biomphalaria glabrata $\left(\mathrm{LC}_{50}=\right.$ $25.5 \mu \mathrm{g} \mathrm{mL}^{-1}$ ). Bioassay-guided fractionation indicated that the activity was concentrated in the alkaloid fraction. Thus, the alkaloid fraction upon CC on Sephadex LH-20 followed by PTLC on Silica gel afforded a new compound, solanandaine, $\mathrm{C}_{45} \mathrm{H}_{73} \mathrm{O}_{16} \mathrm{~N}(\mathbf{1}) \mathrm{mp} 262-263{ }^{\circ} \mathrm{C},[\alpha]_{\mathrm{D}}{ }^{29}-60.0$ ( $\mathrm{MeOH}, c=1.0 \mathrm{mg} \mathrm{mL}^{-1}$ ) along with solasonine (2) and solamargine (3). In this work, we wish to report the isolation, characterization and the molluscicidal activity of the alkaloids of $S$. asperum unripe fruits.

\section{Results and Discussion}

Solanum asperum Rich. is popularly known in Brazil as 'jussara' or 'coça-coça'. It is a neotropical species belonging to the section Brevantherum with wide distribution in South America. Extract of S. asperum unripe fruits demonstrated significant molluscicidal activity. With the aid of biossay-guided fractionation of the crude alkaloid mixture, solanandaine, solasonine and solamargine were isolated from the green fruits of S. asperum. 
Solanandaine (1) was obtained from $\mathrm{MeOH}, \mathrm{mp} 262-263^{\circ} \mathrm{C}$; $[\alpha]_{\mathrm{D}}{ }^{29}-60.0\left(\mathrm{MeOH}, \mathrm{c}=1.0 \mathrm{mg} \mathrm{mL}^{-1}\right)$. The structure of $(\mathbf{1})$ was determined mainly on the basis of positive ion HREIMS and LC-MS along with one and two dimensional ${ }^{1} \mathrm{H}$ and ${ }^{13} \mathrm{C}$ NMR spectral analyses. The assignments of the carbon and proton resonances were made on the basis of HBBD, DEPT, ${ }^{1} \mathrm{H}-{ }^{1} \mathrm{H}$ COSY, HSQC, HMBC and NOESY experiments. The positive ion HREIMS of solanandaine showed a peak at $\mathrm{m} / z$ 884.4964 [M $+\mathrm{H}]^{+}$corresponding to the molecular formula, $\mathrm{C}_{45} \mathrm{H}_{73} \mathrm{O}_{16} \mathrm{~N}$ (calculated for $\mathrm{C}_{45} \mathrm{H}_{74} \mathrm{O}_{16} \mathrm{~N}, 884.4929$ ). The positive ion LC-MS showed, in addition to the one at $\mathrm{m} / \mathrm{z} 884(\mathrm{M}+1)$, significant peaks at $\mathrm{m} / \mathrm{z} 738(\mathrm{M}+\mathrm{H}-146)$, 592 (738 - 146), 430 (592 - 162) and 154. Solanandaine, therefore, contains three hexose units. The sequential loss of 146, 146 and 162 daltons indicate that solanandaine has a rhamnosyl-rhamnosyl-glucosyl side chain attached to an aglycone moiety. There are three typical anomeric proton signals in the ${ }^{1} \mathrm{H}$ NMR spectrum of solanandaine. The one at $\delta_{\mathrm{H}} 4.93(J 7.0 \mathrm{~Hz})$ is certainly due to a $\beta$-D-hexose. The ${ }^{1} \mathrm{H}$ and ${ }^{13} \mathrm{C}$ NMR chemical shifts (Table 1) are fully compatible with a $\beta$-D-glucose structure for this hexose unit. The other two anomeric signals are broad singlets at $\delta_{\mathrm{H}}$ 5.84 and 6.38, typical of $\alpha$-L-rhamnose unities. The HSQC spectrum shows that the three signals at $\delta_{\mathrm{C}} 100.6,102.4$ and 103.2 are due to the corresponding anomeric carbons of the three sugars unities in the glycoside chain.

${ }^{1} \mathrm{H}$ NMR spectrum of solanandaine (Table 1) showed among others the presence of five $\mathrm{CH}_{3}$ signals, two of which are doublets at $\delta_{\mathrm{H}} 1.61(3 \mathrm{H}, J 6.1 \mathrm{~Hz})$ and $1.75(3 \mathrm{H}$, $J 6.2 \mathrm{~Hz}$ ), supporting the presence of two deoxyhexose units like rhamnose and other three are $3 \mathrm{H}$ signals at $\delta_{\mathrm{H}}$ $0.86(\mathrm{~s}), 1.04(\mathrm{~s})$ and $1.08(d, 7.0 \mathrm{~Hz})$. Thus, the aglycone moiety contains only three $\mathrm{CH}_{3}$ groups which suggest that it is not solasodine. The ${ }^{1} \mathrm{H}$ NMR spectrum also showed a signal at $\delta_{\mathrm{H}} 5.30$, characteristic of the $\mathrm{CH}-6$ of $\Delta^{5}$-spirosolanes. The proton decoupled ${ }^{13} \mathrm{C}$ NMR spectrum of solanandaine (Table 1 ) shows the presence of 45 signals for 45 carbons in the molecule. In addition to supporting the presence of five $\mathrm{CH}_{3}$ groups, the spectrum also shows two $\mathrm{CH}_{2}$ signals (DEPT) at $\delta_{\mathrm{C}} 61.6$ and 66.4, typical of two $\mathrm{CH}_{2} \mathrm{OH}$ groups. Therefore, apart from the one in the glucose unit, there must be an additional $\mathrm{CH}_{2} \mathrm{OH}$ group in the aglycone moiety of solanandaine. The absence of one $\mathrm{CH}_{3}$ group compared to solasodine and the appearance of a $\mathrm{CH}_{2} \mathrm{OH}$ group instead strongly suggests the aglycone moiety of solanandaine to be solaparnaine. ${ }^{12}$ The MS peak at $\mathrm{m} / \mathrm{z}, 154.16$ daltons more than the corresponding peak in solasodine at $m / z, 138$ is characteristic of an oxygenated ring $\mathrm{F}$, like that in solaparnaine. ${ }^{13} \mathrm{C}$ NMR spectrum of solanandaine further shows a signal at $\delta_{\mathrm{C}}$ 78.4 for $\mathrm{C}-3$, which is considerably downfield relative to the corresponding shift at $\sim 71.50$ in solasodine or solaparnaine (Table 1). This suggests the presence of sugar substitution at that position of the aglycone. This is further supported by the resulting upfield shifts of C-2 and C-4 to $\delta_{\mathrm{C}} 30.5$ and 39.3, respectively, in solanandaine relative to solasodine or solaparnaine. ${ }^{1}$

Table 2 shows HMBC and NOESY correlations of the protons and carbons of solanandaine. The proton signal at $\delta_{\mathrm{H}} 3.87$ for $\mathrm{H}-3$ has a cross peak with $\delta_{\mathrm{C}} 100.6\left(\mathrm{C}-1^{\prime}\right)$ and the signal at $\delta_{\mathrm{H}} 4.93(\mathrm{~d}, J 7.0 \mathrm{~Hz})$ for $\mathrm{H}^{-1} 1^{\prime}$ shows a cross peak with $\delta_{\mathrm{C}} 78.4(\mathrm{C}-3)$ thereby confirming that a $\beta$-D-glucose unit is indeed substituted at that position. The NOESY spectrum supports this structure. In addition, it shows cross peaks of glycosidic linkages between $\delta_{\mathrm{H}} 4.21$ $\left(\mathrm{H}-2^{\prime}\right)$ and $\delta_{\mathrm{H}} 6.38\left(\mathrm{H}-1^{\prime \prime}\right)$ as well as between $\delta_{\mathrm{H}} 4.35\left(\mathrm{H}-4^{\prime}\right)$ and $\delta_{\mathrm{H}} 5.84\left(\mathrm{H}-1^{\prime \prime \prime}\right)$. This is also supported by HMBC correlations (Table 2). Thus, there are two $\alpha$-L-rhamnose units attached to C-2'and C-4' and an inner $\beta$-D-glucose unit which, in turn, is attached to $\mathrm{C}-3$ of the aglycone unit of solanandaine.

Therefore, the structure of solanandaine must be 3-O-[ $\alpha$-L-rhamnosyl-( $1 \rightarrow 2)$-[ $\alpha$-L-rhamnosyl- $(1 \rightarrow 4)$ $\beta$-D-glucopyranosyl]-solaparnaine (1). The key HMBC correlations are shown on structure 1. Subsequent acid hydrolysis of solanandaine in the usual way furnished solaparnaine (4). Solasonine (2) and solamargine (3) were identified by comparison of their physical and spectral data with those published in the literature. ${ }^{13,14}$

Solanum species are known to produce a great variety of steroidal saponins and glycoalkaloids. The potato glycoalkaloids may have evolved in nature to protect the plant against phytopathogens and other hostile environments. ${ }^{15,16}$ In our previous studies we had found that several species of Solanum, including the unripe fruits of $S$. asperum have potentially significant molluscicidal activity. ${ }^{2,3}$ The crude alkaloid fraction obtained from the active total $\mathrm{MeOH}$ extract as well as the pure alkaloids isolated were tested for the molluscicidal activity (Table 2). Individually, the glykoalkaloids solanandaine (1) $\left(\mathrm{LC}_{50}=73.1 \mu \mathrm{g} \mathrm{mL}^{-1}\right)$, solasonine (2) $\left(\mathrm{LC}_{50}=47.0 \mu \mathrm{g} \mathrm{mL}^{-1}\right)$ and solamargine (3) $\left(\mathrm{LC}_{50}=26.3 \mu \mathrm{g} \mathrm{mL}^{-1}\right)$, were found to be less active than the total $\mathrm{MeOH}\left(\mathrm{LC}_{50}=25.5 \mu \mathrm{g} \mathrm{mL}^{-1}\right)^{3}$ and the crude alkaloidal extracts $\left(\mathrm{LC}_{50}=9.7 \mu \mathrm{g} \mathrm{mL}^{-1}\right)$ of $S$. asperum (Table 3). The higher activity of the crude extracts may be attributed to synergistic effects. The results of the bioassay show that solasonine and solamargine, the glycosides of the common aglycone solasodine, possess more molluscicidal effect and solamargine, with lesser polarity of the two shows relatively more activity. On the other hand, solanandaine, which has an aglycone different than solasonine or solamargine, presents the least bioactivity of all three. These results 
indicate that the activity may be related to both glycosidic and aglycone moieties of the Solanum glycoalkaloids. Earlier, the molluscicidal activity of solasonine and solamargine in a mixture was studied ${ }^{17}$ against Lymnaea cubensis and Biomphalaria glabrata. The toxicity was more pronounced for L. cubensis (100\% mortality, $10 \mathrm{ppm}$ ) and B. glabrata (100\% mortality, $25 \mathrm{ppm}$ ). In the present work, we studied the activity of the individual glycoalkaloids in the bioassay with $B$. glabrata upon which the $\mathrm{LC}_{50}$ values were calculated. The molluscicidal activity seen in some Solanum species is generally attributed to the presence of glycoalkaloids, with other classes of secondary metabolites, including alkamines, having litte if any such activity. ${ }^{17}$ Besides solasonine and solamargine, others glycoalkaloids of Solanum as tomatine ${ }^{17}$ and solamarine ${ }^{18}$ presents molluscicidal activity.

\section{Experimental}

\section{General}

Melting points were determined on a Koefler hot stage and are uncorrected. Optical rotation was measured with a Bellingham \& Stanley Ltd., Model ADP220 polarimeter. The infrared absorption spectra were recorded in $\mathrm{KBr}$ pellets, using a Bomem/MB-102 spectrophotometer operating in the $4000-400 \mathrm{~cm}^{-1}$ range. The LC-MS was obtained in positive electrospray mode using a Quattro LC-Micromass (Waters) and HREIMS were obtained by electron impact on a VG Autospec spectrometer. TLC was done using silica gel Kieselgel 60 (E. Merck) and spots were visualized by Dragendorff reagent. ${ }^{1} \mathrm{H}$ and ${ }^{13} \mathrm{C}$ NMR spectra were obtained using a Bruker Advance $500(500 \mathrm{~Hz}$ for ${ }^{1} \mathrm{H}$ and $125 \mathrm{MHz}$ for ${ }^{13} \mathrm{C}$ ) Spectrometer as well as a Jeol Eclipse+ 400 spectrometer operating at $400 \mathrm{MHz}$ in pyridine- $d_{5}$. Sephadex LH-20 (Sigma) was employed for gel permeation chromatography.

\section{Plant material}

Fruits of S. asperum were collected in the State of Paraíba, Brazil, in September 2005 from a secondary vegetation of the Atlantic forest area at the campus of the Universidade Federal da Paraíba, in the municipality of João Pessoa, at 130 to $160 \mathrm{~m}$ elevation. The plant was identified by Dr. Maria de Fátima Agra (LTF-UFPB). Voucher specimen (Agra 1243) is deposited at the Prof. Lauro Pires Xavier (JPB) Herbarium, Universidade Federal da Paraíba, João Pessoa, Brazil.

\section{Extraction and isolation}

Fresh fruits of $S$. asperum (740.0 g) were extracted with $\mathrm{H}_{2} \mathrm{O}: \mathrm{HOAc}(8: 2)$ in a blender and filtered through a bed of Celite. The acid aqueous filtrate was basified with $\mathrm{NH}_{4} \mathrm{OH}$ and left standing overnight. The gelatinous precipitate $(10.1 \mathrm{~g})$ formed was collected by filtration to give a mixture of glycoalkaloids. The alkaloid mixture was then chromatographed over Sephadex LH-20 using $\mathrm{MeOH}$ as eluent and fifteen fractions were collected. Fractions 3-10 showed the presence of alkaloids. Fraction 4 (850.0 mg) with three alkaloids was further purified by PTLC in silica gel plates and eluted with $\mathrm{CH}_{2} \mathrm{Cl}_{2}: \mathrm{MeOH}: \mathrm{NH}_{3}$ (9:2:0.5) to furnish solanandaine $(\mathbf{1}, 120.0 \mathrm{mg})$, solasonine $(\mathbf{2}, 450.0 \mathrm{mg})$ and solamargine $(\mathbf{3}, 172.0 \mathrm{mg})$.

Solanandaine (1): white powder $(\mathrm{MeOH}) ; \mathrm{mp} 262$ $-263{ }^{\circ} \mathrm{C} ;[\alpha]_{\mathrm{D}}^{29}-60.0\left(\mathrm{MeOH}, \mathrm{c}=1.0 \mathrm{mg} \mathrm{mL}^{-1}\right)$; IR $(\mathrm{KBr})$ 3450, 2940, 1625, 1071, 1045, $980 \mathrm{~cm}^{-1} ;{ }^{1} \mathrm{H} \mathrm{NMR}$ and ${ }^{13} \mathrm{C}$ NMR (pyridine- $d_{5}, 500 \mathrm{MHz}$ and $125 \mathrm{MHz}$, respectively), see Tables 1 and 2. Positive-ion HREIMS $\mathrm{m} / \mathrm{z} 884.4964$ (calculated for $\left.\mathrm{C}_{45} \mathrm{H}_{74} \mathrm{O}_{16} \mathrm{~N},[\mathrm{M}+\mathrm{H}]^{+}, 884.4929\right)$.

\section{Molluscicidal tests}

Molluscicidal activity of the crude alkaloid fraction and the individual glycoalkaloids was measured according to

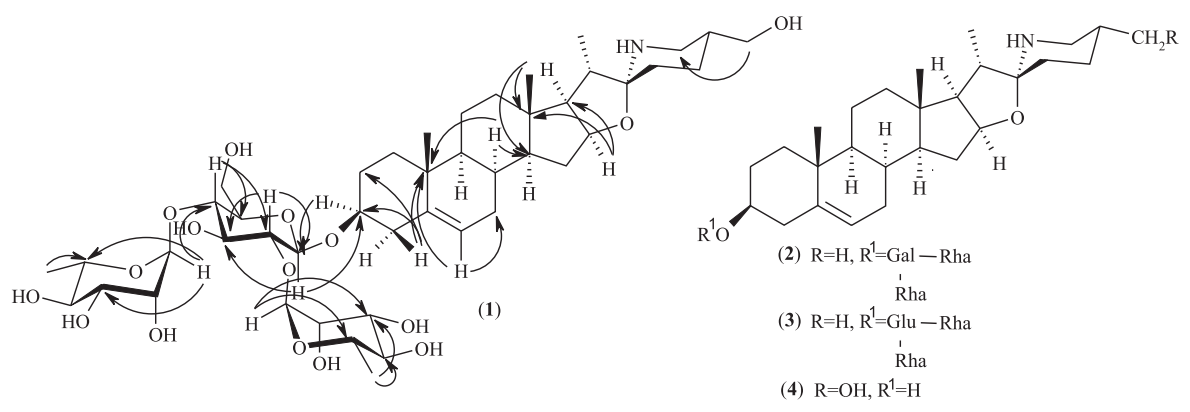

Figure 1. Solanandaine (1), Solasonine (2), Solamargine (3) and Solaparnaine (4). 
Table 1. ${ }^{1} \mathrm{H}$ NMR $(500 \mathrm{MHz})$ and ${ }^{13} \mathrm{C}$ NMR $(125 \mathrm{MHz})$ spectral data of solanandaine (1) in pyridine- $d_{5}$. Chemical shifts are in $\delta$ ppm and coupling constants $(J=\mathrm{Hz})$ are given in parenthesis ${ }^{\mathrm{a}}$

\begin{tabular}{|c|c|c|c|c|c|}
\hline Carbon & $\delta_{\mathrm{C}}$ & $\delta_{\mathrm{H}}$ & Carbon & $\delta_{\mathrm{C}}$ & $\delta_{\mathrm{H}}$ \\
\hline 1 & 37.8 & a) $1.71 ;$ b) 0.98 & Glu & & \\
\hline 2 & 30.5 & a) 2.09 ; b) 1.88 & 1 ' & 100.6 & $4.93(\mathrm{~d}, 7.0)$ \\
\hline 3 & 78.4 & $3.87(\mathrm{~m})$ & 2 ' & 78.1 & 4.21 \\
\hline 4 & 39.3 & a) $2.80 ;$ b) 2.74 & 3, & 78.2 & 4.19 \\
\hline 5 & 141.1 & & $4^{\prime}$ & 78.9 & 4.35 \\
\hline 6 & 122.2 & $5.30(\mathrm{br}, \mathrm{s})$ & 5, & 77.2 & 3.63 (br, d, 9.2) \\
\hline 7 & 32.7 & 1.86 & 6 & 61.6 & a) 4.21 ; b) 4.07 \\
\hline 8 & 31.9 & 1.54 & Rha & & \\
\hline 9 & 50.6 & 0.89 & $1 ”$ & 102.4 & $6.38(\mathrm{~s})$ \\
\hline 10 & 37.4 & & $2 "$ & 72.8 & $4.83(\mathrm{br}, \mathrm{s})$ \\
\hline 11 & 21.4 & 1.45 & $3 "$ & 73.0 & $4.62(\mathrm{dd}, 9.3 ; 3.0)$ \\
\hline 12 & 40.4 & a) $1.69 ;$ b) 1.11 & $4 "$ & 74.4 & $4.36(t, 9.6)$ \\
\hline 13 & 41.0 & & $5 "$ & 69.9 & 4.94 (br, d, 9.4) \\
\hline 14 & 57.0 & 1.05 & $6 "$ & 19.0 & $1.75(\mathrm{~d}, 6.2)$ \\
\hline 15 & 32.9 & a) $2.08 ;$ b) 1.45 & Rha & & \\
\hline 16 & 79.1 & $4.43(\mathrm{~m})$ & $1, "$ & 103.2 & $5.84(\mathrm{~s})$ \\
\hline 17 & 63.8 & 1.81 & $2, "$ & 72.8 & $4.68(\mathrm{br}, \mathrm{s})$ \\
\hline 18 & 16.8 & $0.86(\mathrm{~s})$ & $3^{\prime \prime}$ & 73.0 & $4.53(\mathrm{dd}, 9.3,3.0)$ \\
\hline 19 & 19.7 & $1.04(\mathrm{~s})$ & $4, "$ & 74.2 & $4.34(\mathrm{t}, 9.4)$ \\
\hline 20 & 42.0 & $1.97(\mathrm{~m})$ & $5^{\prime \prime}$ & 70.7 & $4.89(\mathrm{~m})$ \\
\hline 21 & 16.0 & $1.08(\mathrm{~d}, 7.0)$ & $6 "$, & 18.8 & $1.61(\mathrm{~d}, 6.1)$ \\
\hline 22 & 99.3 & & & & \\
\hline 23 & 34.6 & a) 1.78 ; b) 1.67 & & & \\
\hline 24 & 26.1 & 1.84 & & & \\
\hline 25 & 40.5 & 2.05 & & & \\
\hline 26 & 44.4 & a)3.33; b)3.09 & & & \\
\hline 27 & 66.4 & $3.71(\mathrm{~m})$ & & & \\
\hline
\end{tabular}

Superimposed ${ }^{1} \mathrm{H}$ signals are described without multiplicity.

Table 2. Significant HMBC and NOESY correlations for solanandaine (1)

\begin{tabular}{|c|c|c|c|}
\hline Protons & $\delta_{\mathrm{H}}$ & NOESY & Correlated C \\
\hline H-1 & $1.71 ; 0.98$ & H-3 & C-19 \\
\hline $\mathrm{H}-3$ & 3.87 & $\mathrm{H}-1 ; \mathrm{H}-1$, & $\mathrm{C}-1$, \\
\hline H-4 & $2.80 \alpha ; 2.74 \beta$ & H-3; H-6 & $\mathrm{C}-2 ; \mathrm{C}-3 ; \mathrm{C}-10$ \\
\hline H-6 & 5.30 & H-4 $\alpha ; \mathrm{H}-7$ & C-7; C-10 \\
\hline $\mathrm{H}-8$ & 1.54 & & C-10; C-14; C-15 \\
\hline $\mathrm{H}-11$ & 1.45 & H-9; H-19 & C-9 \\
\hline $\mathrm{H}-14$ & 1.05 & H- $15 \beta ; H-18$ & \\
\hline $\mathrm{H}-16$ & 4.43 & $H-15 \alpha$ & C-13; C-17 \\
\hline H-18 & 0.86 & $\mathrm{H}-20$ & C-13; C-14 \\
\hline H-19 & 1.04 & $\mathrm{H}-11$ & C-1; C-5 \\
\hline $\mathrm{H}-21$ & 1.08 & $\mathrm{H}-16$ & $C-16 ; C-22$ \\
\hline $\mathrm{H}-27$ & 3.71 & & C-26 \\
\hline $\mathrm{H}-1$, & 4.93 & H-3; H-2'; H-5, & C-3; C-3' \\
\hline $\mathrm{H}-2^{\prime}$ & 4.20 & 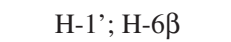 & $\mathrm{C}-1 ; \mathrm{C}-3$, \\
\hline H-3, & 4.19 & $\mathrm{H}-1 "$ & C- 4 \\
\hline $\mathrm{H}-4$, & 4.35 & H-2'; H-5'”' & $\mathrm{C}-3^{\prime} ; \mathrm{C}-5^{\prime} ; \mathrm{C}-1^{\prime \prime}$ \\
\hline $\mathrm{H}-1 "$ & 6.37 & H-2'; H-2"' & $\mathrm{C}-3^{\prime}, \mathrm{C}-3^{\prime \prime} ; \mathrm{C}-5^{\prime \prime}$ \\
\hline $1 "$, & 5.84 & $\begin{array}{c}\text { H-2'”; } \mathrm{H}-4 \text { '; H-6a, } \\
\text { H-6b }\end{array}$ & C-4', C-2"'; C-5"' \\
\hline $4 "$ & 4.36 & H-1"' & C-3", C-5" \\
\hline H-6" & 1.75 & H-5” & C-4"; C-5" \\
\hline H-6"”, & 1.61 & H-5"'; H-4, & C-5"'; C-4"' \\
\hline
\end{tabular}

Table 3. Lethal concentrations and molluscicidal activity of crude extracts and pure alkaloids to kill $90 \%, 50 \%$ and $10 \%$ of Biomphalaria glabrata exposed at $24 \mathrm{~h}$ experiment

\begin{tabular}{lccc}
\hline & \multicolumn{3}{c}{ Concentration $\mu \mathrm{g} \mathrm{mL}^{-1} /(\mathrm{nM})$} \\
\hline Samples Tested & $\mathrm{LC}_{90}$ & $\mathrm{LC}_{50}$ & $\mathrm{LC}_{10}$ \\
MeOH Extract* & 44.1 & 25.1 & 7.0 \\
Alkaloidal fraction & 17.33 & 9.7 & 2.9 \\
Solanandaine (1) & 99.7 & $73.1(82.7)$ & $46.4(52.5)$ \\
Solasonine (2) & $(112.8)$ & & \\
Solamargine (3) & $63.0(82.9)$ & $47.0(53.1)$ & $22.0(25.3)$ \\
\hline
\end{tabular}

*Ref 3 .

the method described ${ }^{3}$ using laboratory-bred B. glabrata as the target snails. The samples were dissolved in three drops of Cremophor emulsifier (BASF, Ludwigshafen, Germany) and dechlorinated water to give stock solutions containing $100 \mu \mathrm{g} \mathrm{mL}^{-1}$ of each of the samples of crude alkaloid extracts and pure glycoalkaloids. For the preliminary bio-assays, each stock solution was either left undiluted 
or further diluted with dechlorinated water to give test solutions containing 100,50 and $10 \mu \mathrm{g} \mathrm{mL}^{-1}$ of the samples. Subsequently, five different test solutions, ranging in concentration from 10 to $100 \mu \mathrm{g} \mathrm{mL}^{-1}$ were prepared. For each assay, 10 adult snails (measuring $8-12 \mathrm{~mm}$ diameter) were exposed to $250 \mathrm{~mL}$ of each test solution in a glass beaker for $24 \mathrm{~h}$ at room temperature. After this period, each test solution was replaced with dechlorinated water. Snail mortality was then recorded over the following $24 \mathrm{~h}$ period, and compared with the positive controls (cupric carbonate at $50 \mu \mathrm{g} \mathrm{mL}^{-1}$ ) and negative controls (extractfree dechlorinated water containing the same amount of Cremophor as the stock solutions). All assays were run in duplicate. The concentrations that kill $90 \%\left(\mathrm{LC}_{90}\right), 50 \%$ $\left(\mathrm{LC}_{50}\right)$ and $10 \%\left(\mathrm{LC}_{10}\right)$ of the treated snails (survived in the negative control cultures) were estimated by probit analysis, using the Origin 6.0

\section{Acknowledgments}

The authors thank IMSEAR-CNPq, CAPES and PIBICUFPB for financial support. JB thanks CAPES for generous support of Visiting Professorship. TMSS thanks Prof. Edilberto R. Silveira and Daniel E. Uchoa (CENAUREM Centro Nordestino de Aplicação e Uso de RMN) and Prof. Raimundo Braz-Filho (UENF-RJ) for kindly recording the NMR data, and Socrates Golzio (LTF-UFPB) for kindly recording the LC-MS data.

\section{Supplementary Information}

Supplementary data of the isolated compounds as ${ }^{13} \mathrm{C}$ and ${ }^{1} \mathrm{H}$ NMR spectra are available free of charge at http://jbcs.sbq.org.br, as PDF file.

\section{References}

1. Agra, M. F.; Bhattacharyya, J. In Solanaceae. IV, Advances in Biology and Utilization; Nee, M.; Symon, D. E.; Lester, R. N.; Jessop, J. P. eds.; Royal Botanic Gardens: Kew, U.K., 1999, pp. 341-343.

2. Silva, T. M. S.; Camara, C. A.; Agra, M. F.; Carvalho, M. G.; Frana, M. T.; Brandolini, S. V. P. B.; Paschoal, L. S.; Braz-Filho, R.; Fitoterapia 2006, 77, 449.

3. Silva, T. M. S.; Batista, M. M.; Camara, C. A.; Agra, M. F.; Ann. Trop. Med. Parasitol. 2005, 4, 419.

4. Hostettmann, K.; Kizu, H.; Tomimori, T.; Planta Medica 1982, $44,34$.

5. Marston, A.; Hostettmann, K.; Phytochemistry 1985, 24, 639.

6. Silva, T. M. S.; Braz-Filho, R.; Carvalho, M. G.; Agra, M. F.; Biochem. System. Ecol. 2002, 30, 1083.

7. Silva, T. M. S.; Braz-Filho, R.; Carvalho, M. G.; Agra, M. F.; Biochem. System. Ecol. 2002, 30, 479.

8. Silva, T. M. S.; Nascimento, R. J. B.; Camara, C. A.; Agra, M. F.; Braz-Filho, R.; Carvalho, M. G.; Biochem. System. Ecol. 2004, 32, 513.

9. Esteves-Souza, A.; Silva, T. M. S.; Alves, C. C. F.; Carvalho, M. G.; Braz-Filho, R.; Echevarria, A.; J. Braz. Chem. Soc. 2002, 13,838 .

10. Silva, T. M. S.; Costa, R. A.; Oliveira, E. J.; Barbosa-Filho, J. M.; Agra, M. F.; Camara, C. A.; J. Braz. Chem. Soc. 2005, 16, 1467.

11. Silva, T. M. S.; Nascimento, R. J. B.; Batista, M. M.; Agra, M. F.; Barbosa-Filho, J. M.; Camara, C. A.; Rev. Bras. Farmacogn. 2006, 17, 35 .

12. Bhattacharyya, J.; Heterocycles 1985, 23, 3111.

13. Puri, R.; Wong, T. C.; J. Nat. Prod. 1994, 57, 587.

14. Fukuhara, K.; Kubo, I.; Phytochemistry 1991, 30, 685.

15. Friedman, M.; Rayburn, J. R.; Bantle, J. A.; Food Chem. Toxicol. 1991, 29, 537.

16. Friedman, M.; J. Agric. Food. Chem. 2006, 54, 8655.

17. Alzerreca, A.; Hart, G.; Toxicol. Lett. 1982, 12, 151.

18. Wanyonyi, A. W.; Chlabra, S. C.; Mkoji, G.; Eilert, U.; Njue, W. M.; Phytochemistry 2002, 59, 79. 


\section{The Steroidal Glycoalkaloids and Molluscicidal Activity of Solanum asperum Rich. Fruits}

Tania M. S. Silva, ${ }^{*, a}$ Celso A. Camara, ${ }^{b}$ Kristerson R. L. Freire, ${ }^{c}$ Thiago G. da Silva, ${ }^{c}$ Maria de F. Agrac and Jnanabrata Bhattacharyya ${ }^{c}$

${ }^{a}$ Núcleo Complexo Produtivo de Saúde, Instituto Multidisciplinar em Saúde, Campus Avançado Anísio Teixeira, Avenida Olívia Flores, 3000, Candeias, 45055-090 Vitória da Conquista-BA, Brazil

${ }^{b}$ Departamento de Química, Universidade Federal Rural de Pernambuco, R. Dom Manoel de Medeiros, $s / n$, Dois Irmãos, 52171-900 Recife-PE, Brazil

${ }^{c}$ Laboratório de Tecnologia Farmacêutica, Universidade Federal da Paraíba, CP 5009, 58051-970 João Pessoa-PB, Brazil

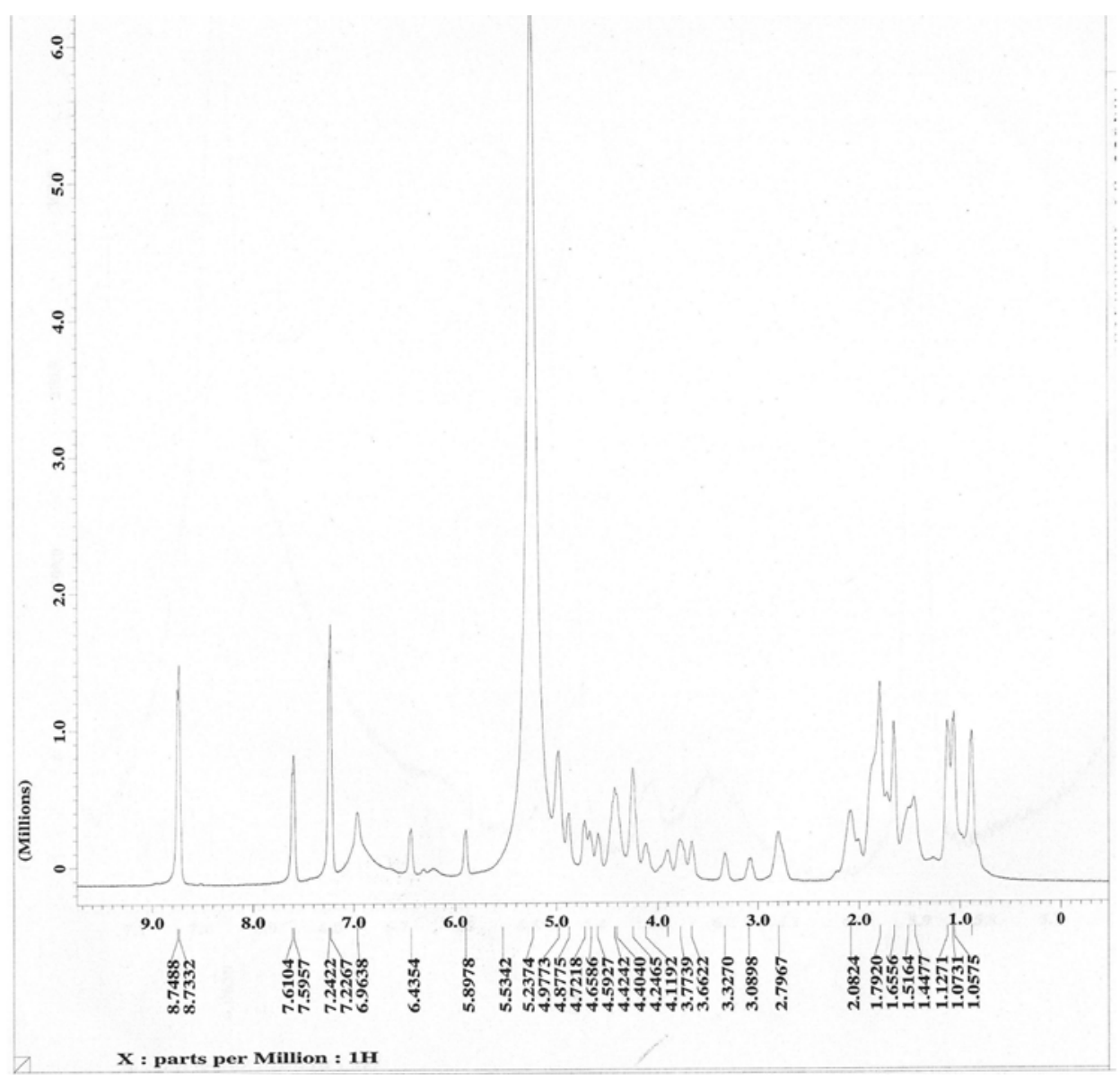

Figure S1. ${ }^{1} \mathrm{H}$ NMR (400 MHz, Pyridine- $d_{5}$ ) spectrum of solanandaine (1).

*e-mail: sarmento@pesquisador.cnpq.br 


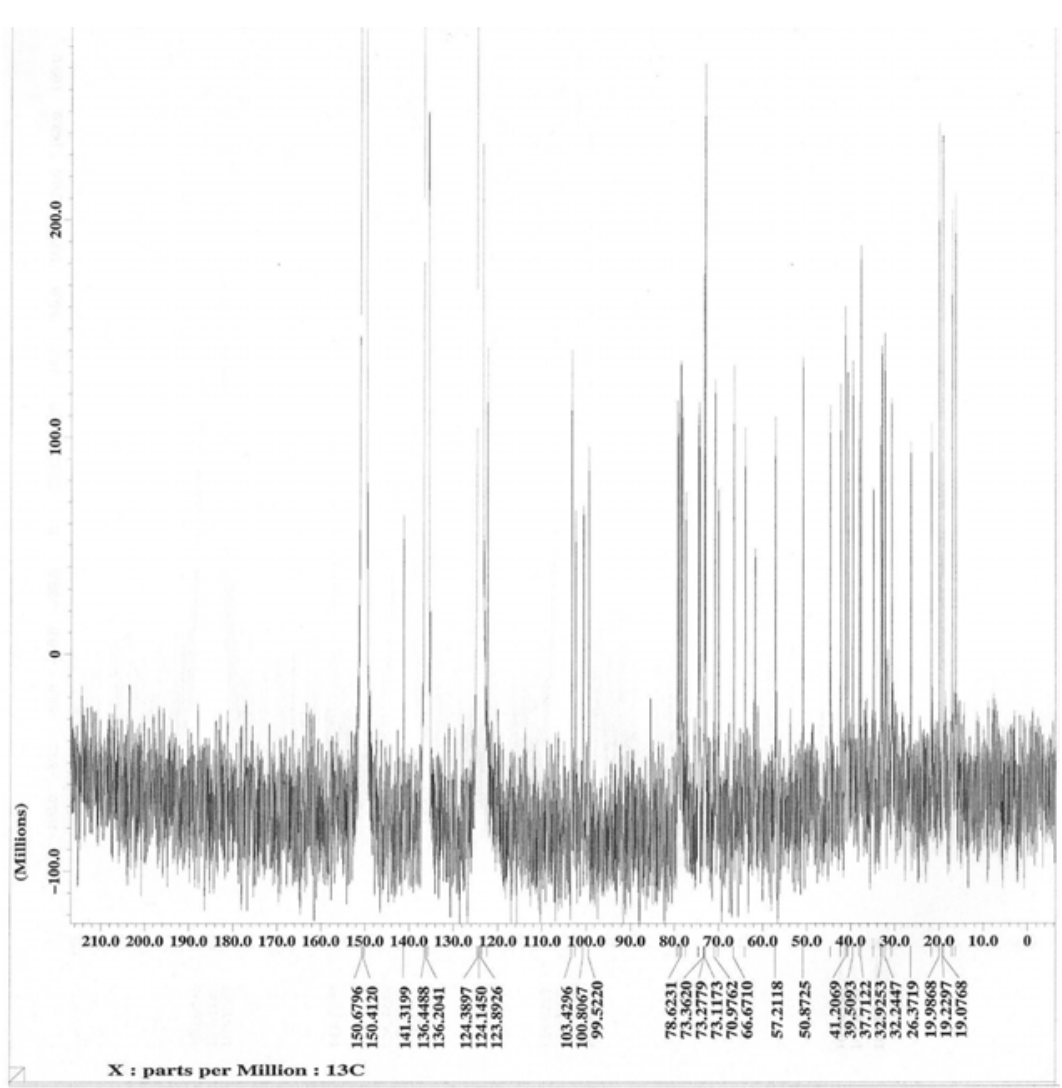

Figure S2. ${ }^{13} \mathrm{C}$ NMR (100 MHz, Pyridine- $d_{5}$ ) spectrum of solanandaine (1).

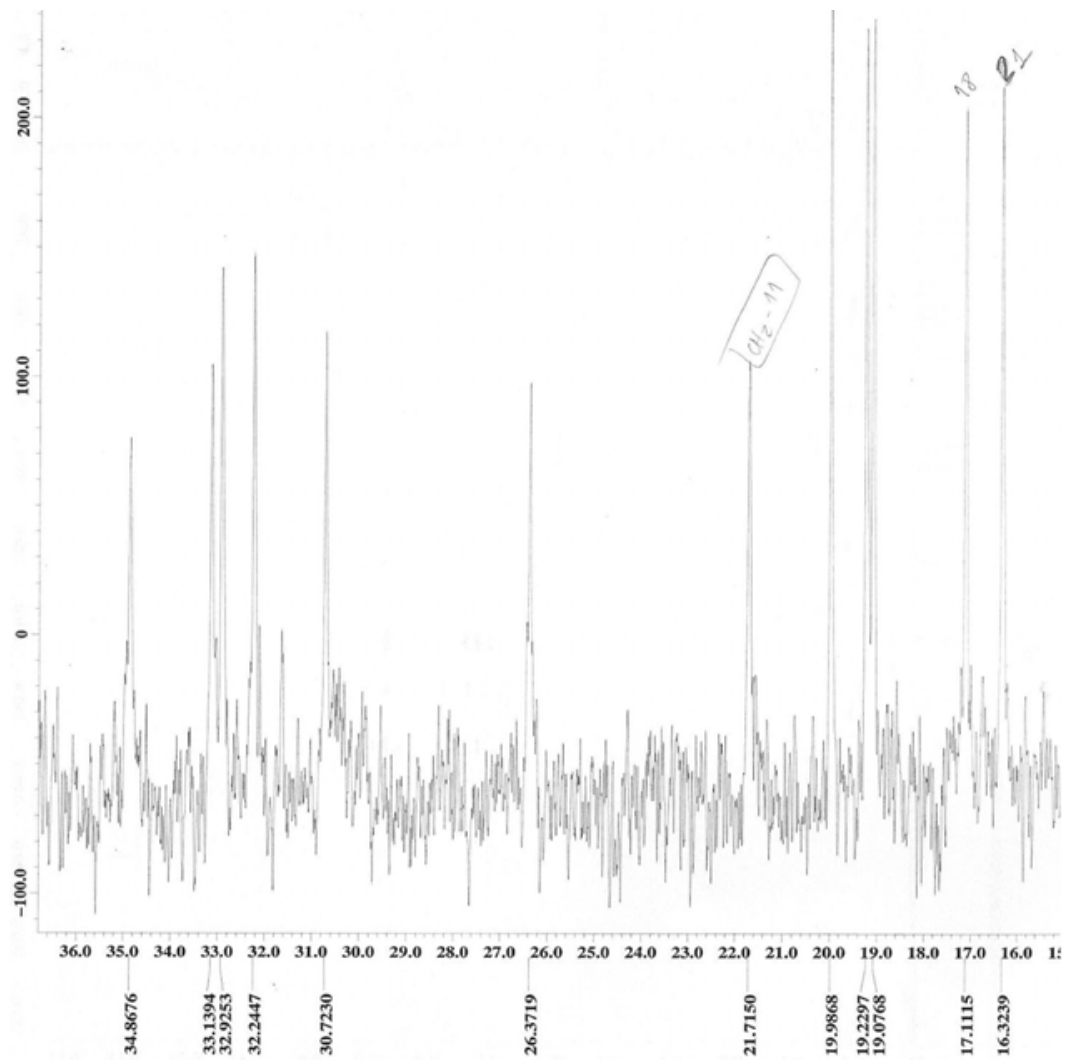

Figure S3. ${ }^{13} \mathrm{C}$ NMR spectrum (100 MHz, Pyridine- $d_{5}$ ) expansion upfield of solanandaine (1). 


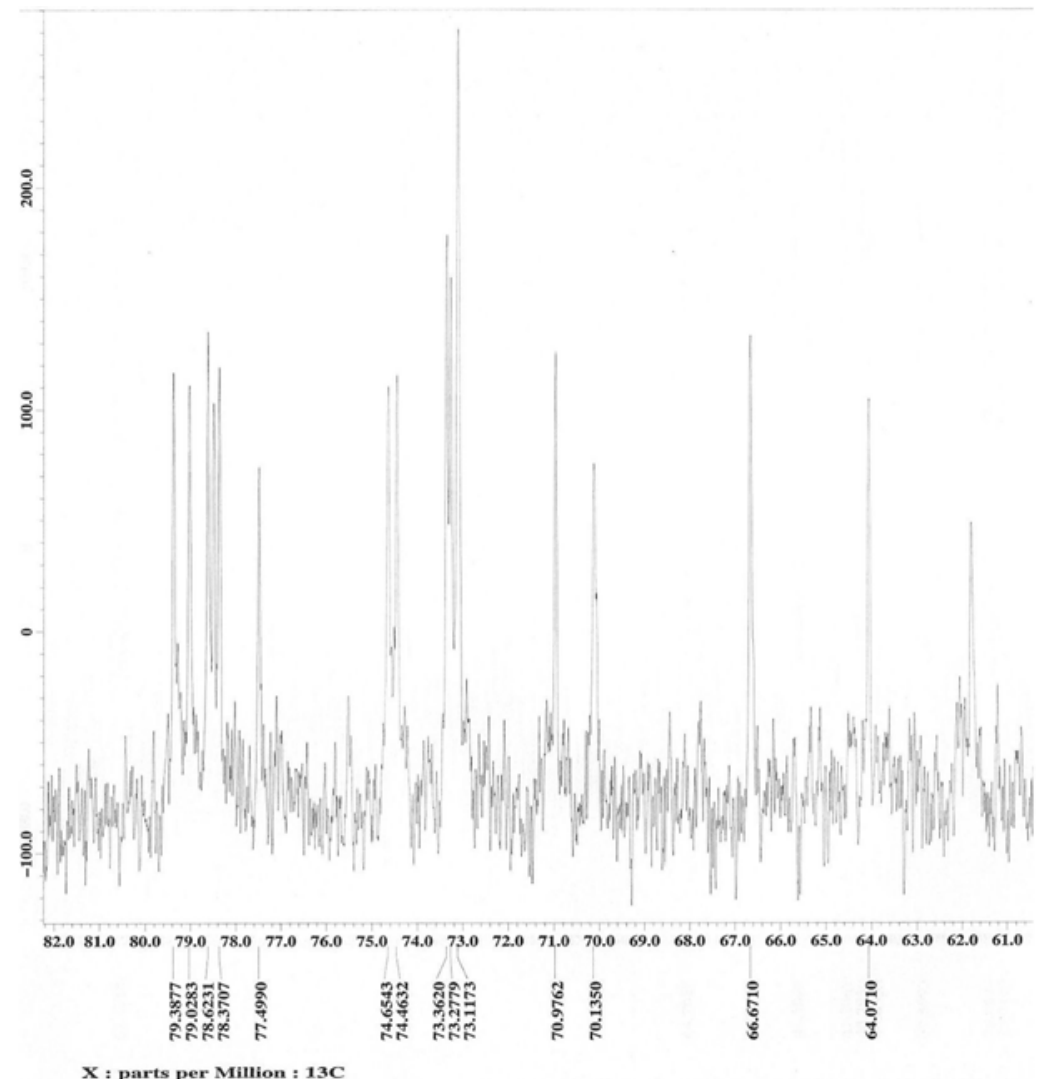

Figure S4. ${ }^{13} \mathrm{C}$ NMR spectrum (100 MHz, Pyridine- $d_{5}$ ) expansion downfield of solanandaine.

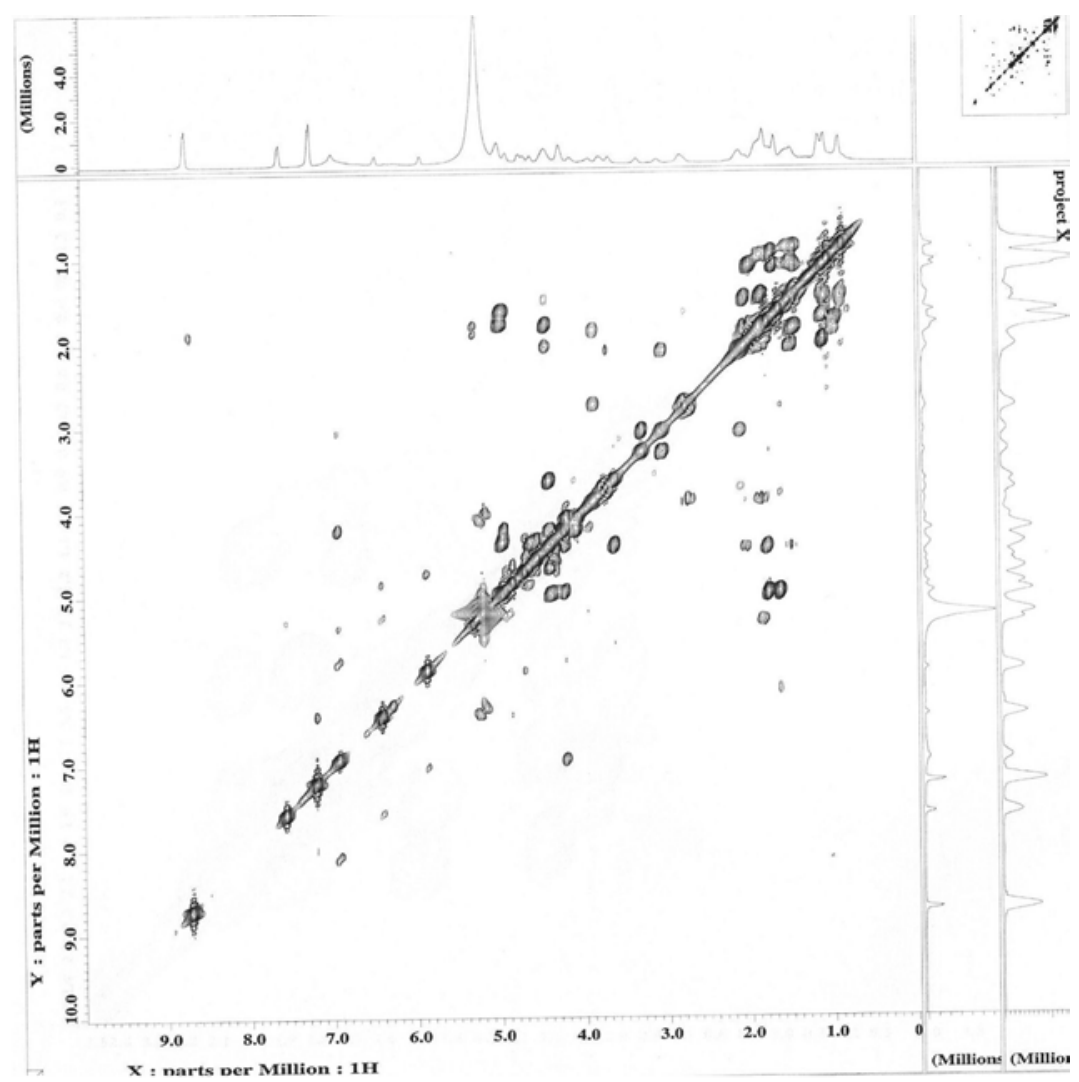

Figure S5. COSY spectrum ('H NMR: $400 \mathrm{MHz}$, Pyridine- $d_{5}$ ) of solanandaine (1). 


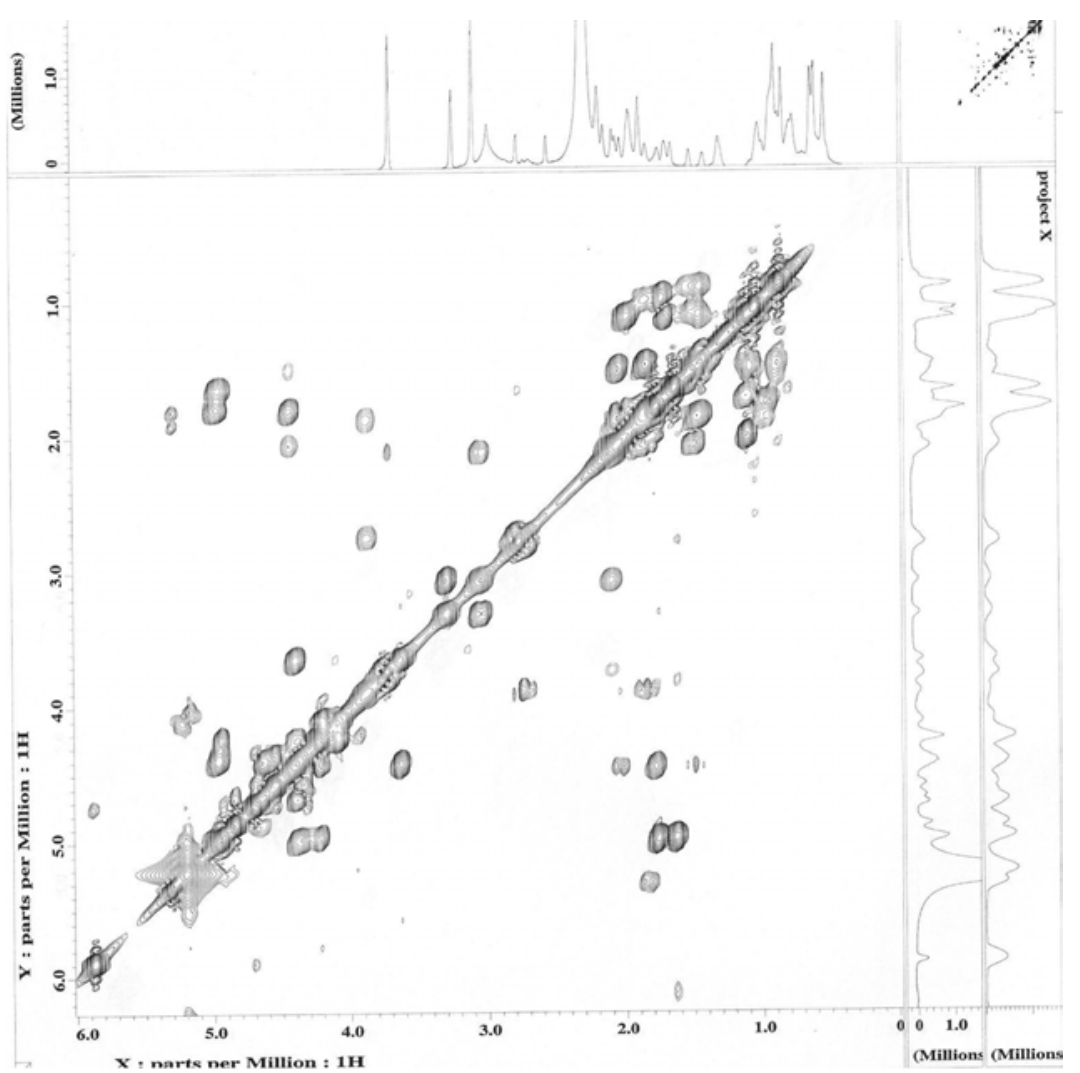

Figure S6. COSY spectrum ('H NMR: $400 \mathrm{MHz}$, Pyridine- $d_{5}$ ) expansion upfield of solanandaine (1).

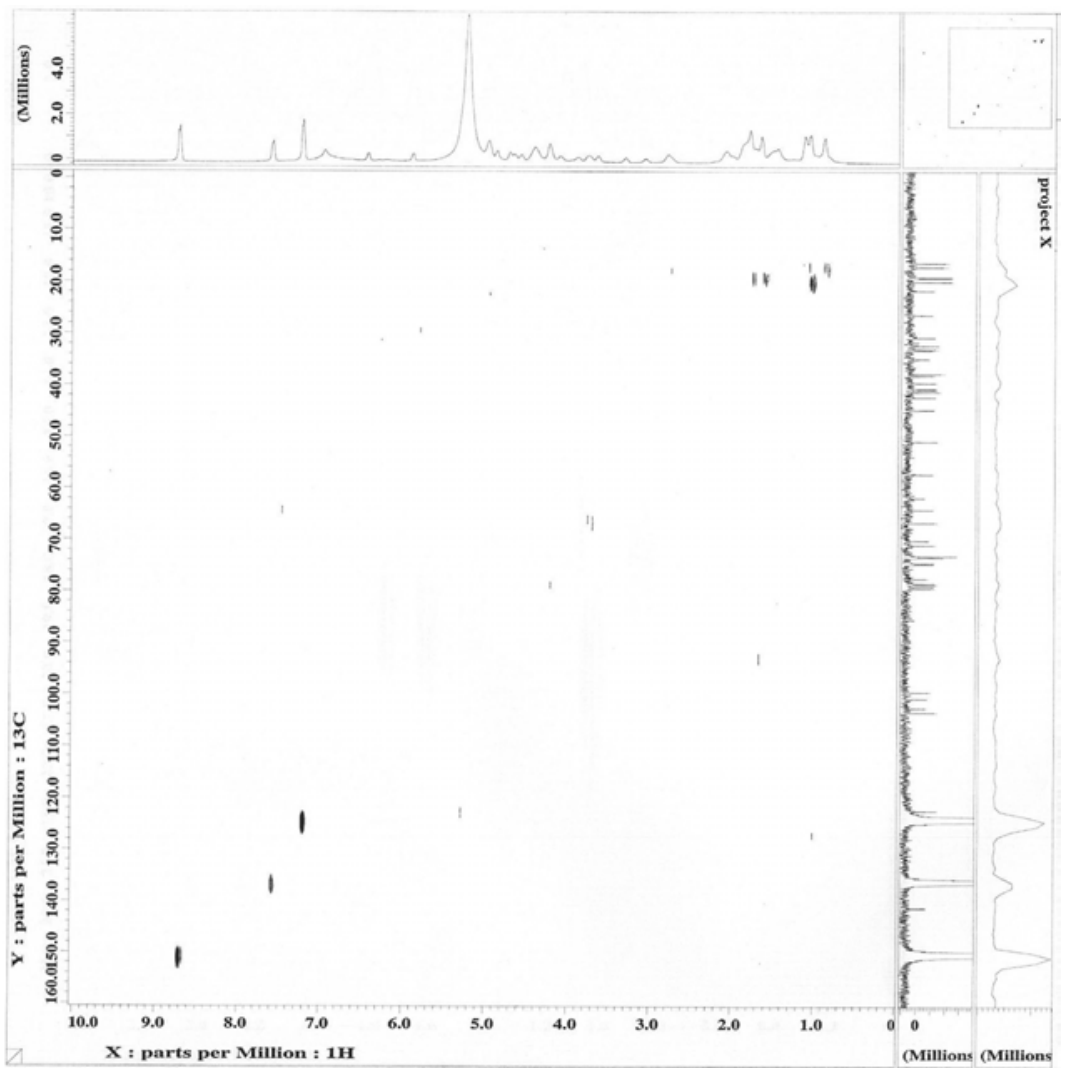

Figure S7. HMQC spectrum ( ${ }^{1} \mathrm{H}$ NMR: $400 \mathrm{MHz},{ }^{13} \mathrm{C}$ NMR: $100 \mathrm{MHz}$, Pyridine- $d_{5}$ ) of solanandaine (1). 


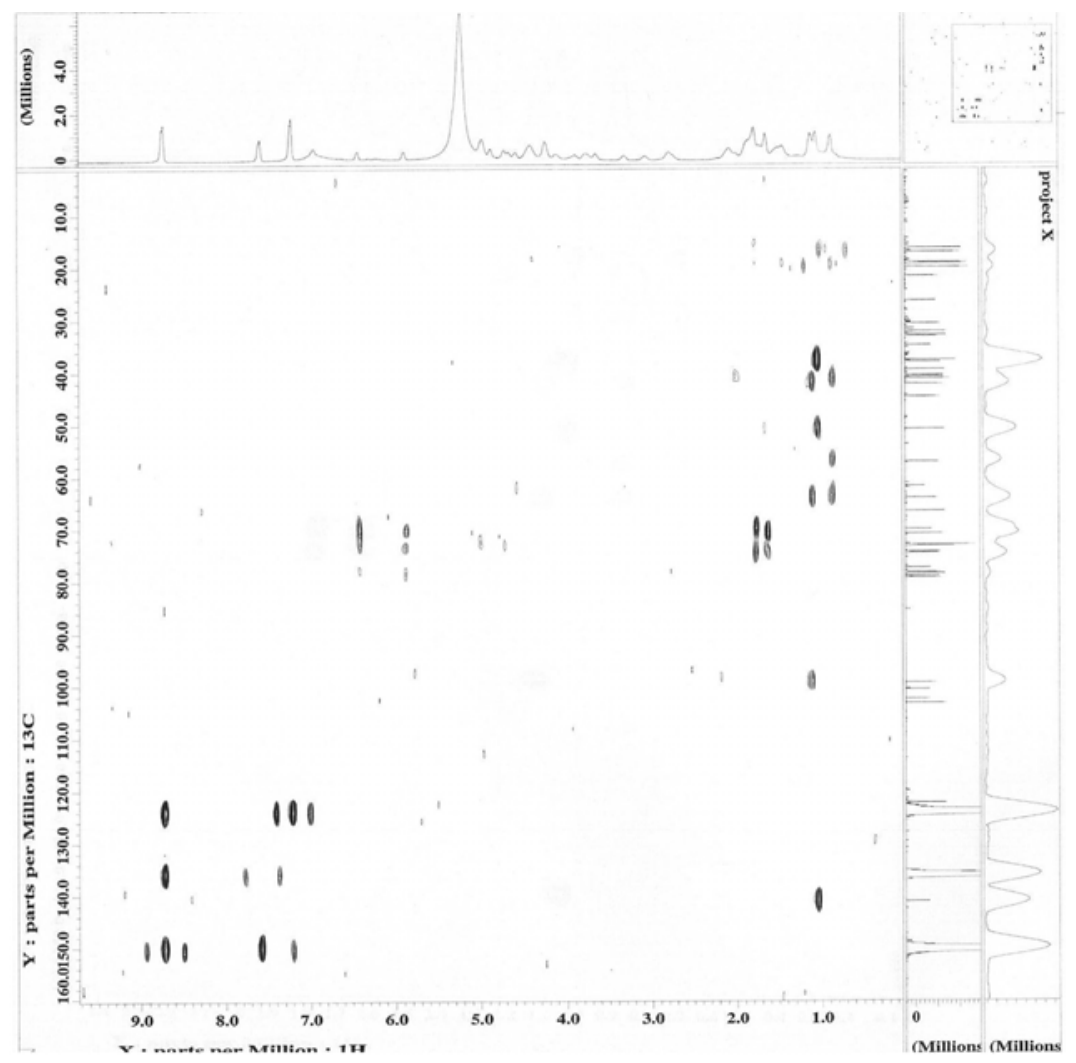

Figure S8. HMBC spectrum ( $\left({ }^{1} \mathrm{H}\right.$ NMR: $400 \mathrm{MHz},{ }^{13} \mathrm{C}$ NMR: $100 \mathrm{MHz}$, Pyridine- $d_{5}$ ) of solanandaine (1).

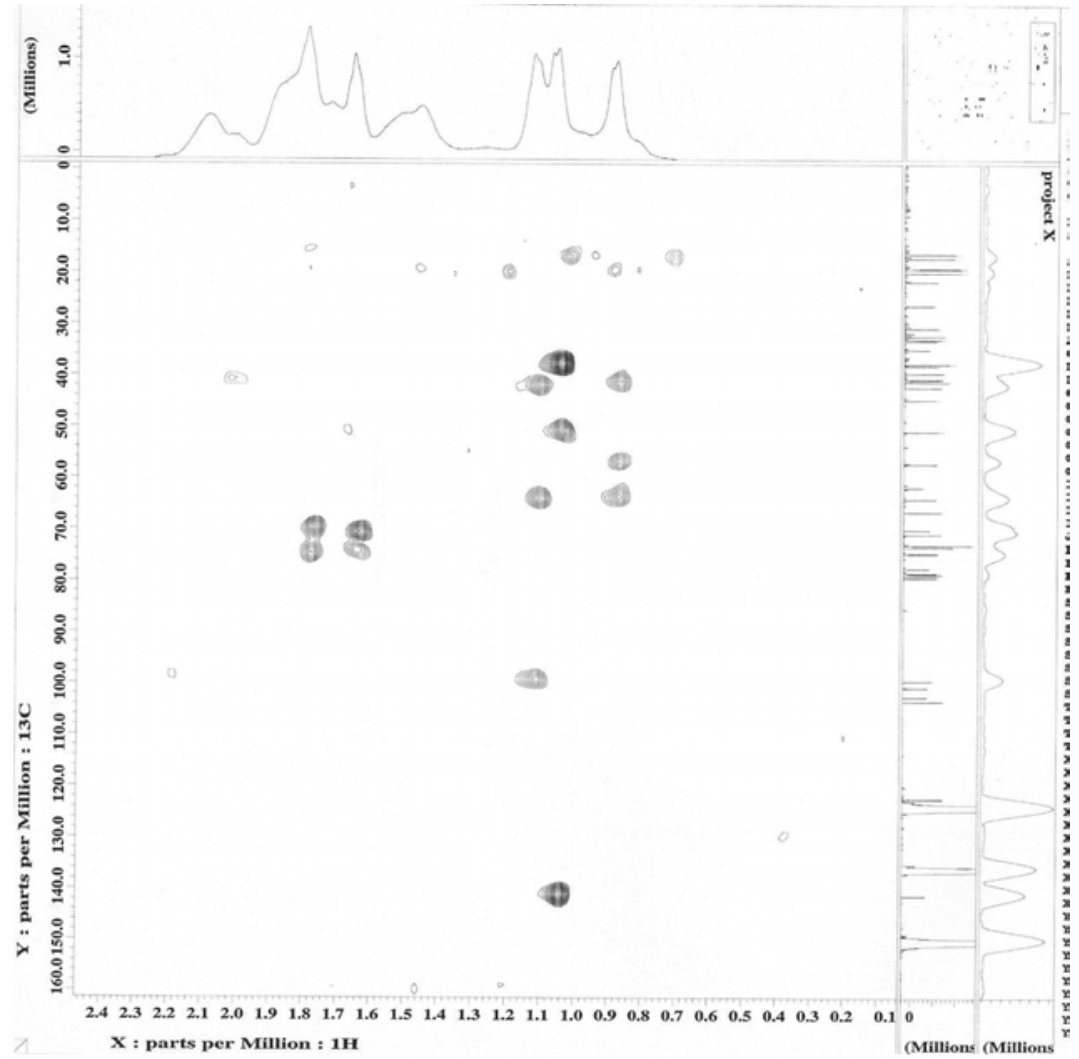

Figure S9. HMBC spectrum ( ${ }^{1} \mathrm{H}$ NMR: $400 \mathrm{MHz},{ }^{13} \mathrm{C}$ NMR: $100 \mathrm{MHz}$, Pyridine- $d_{5}$ ) expansion upfield of solanandaine (1). 


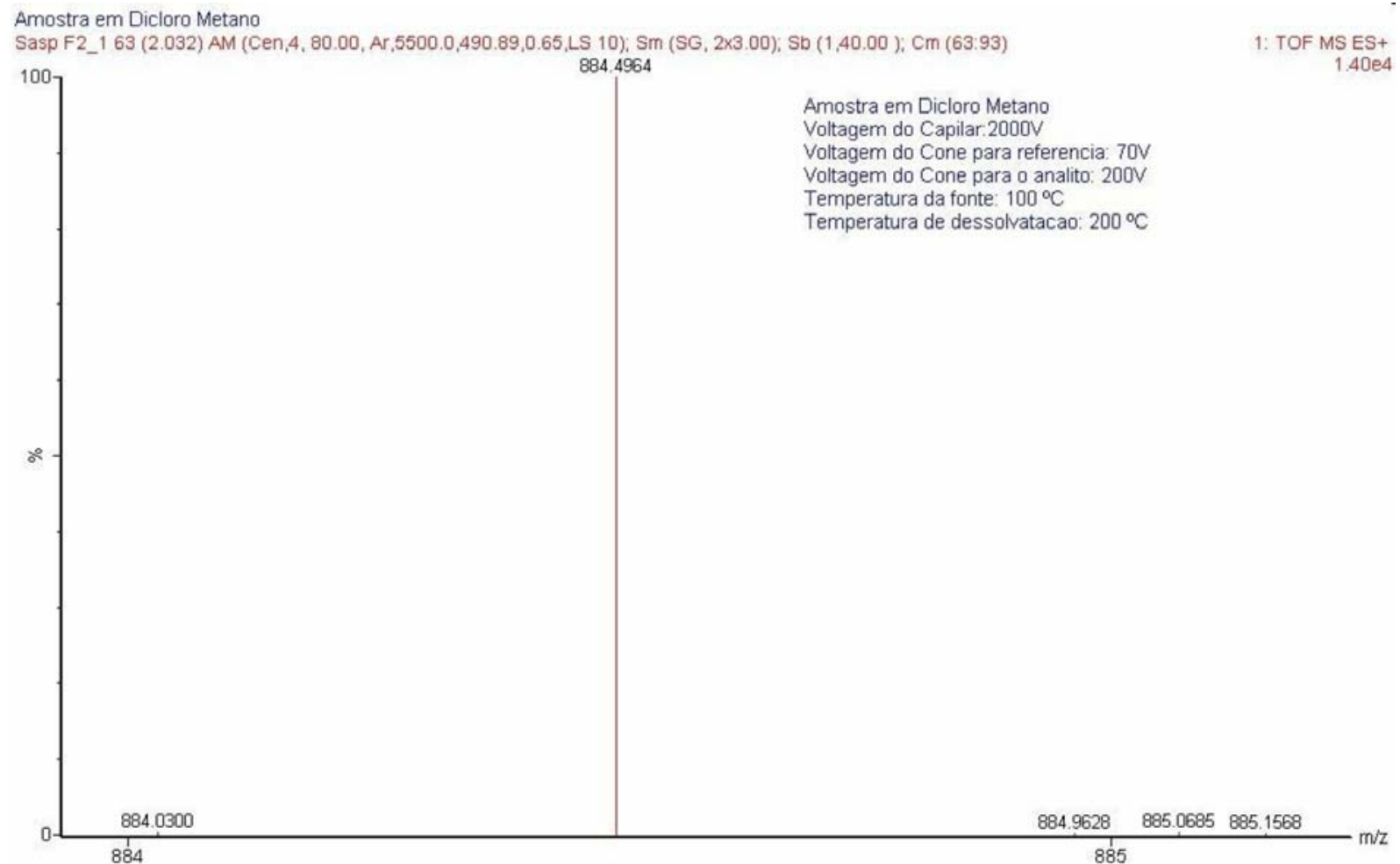

Figure S10. HREIMS (70 eV) spectrum of solanandaine (1).

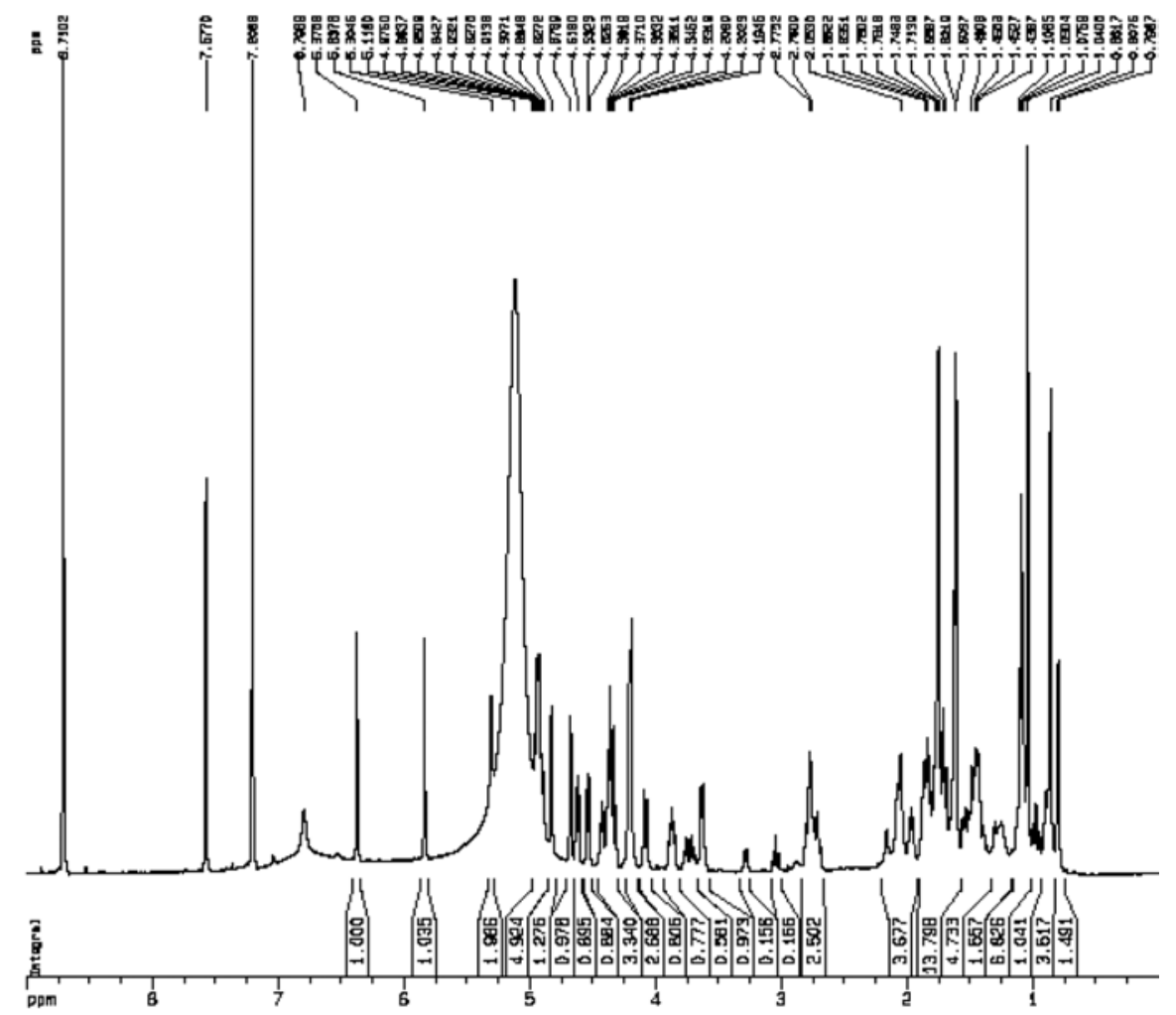

Figure S11. ${ }^{1} \mathrm{H}$ NMR (500 MHz, Pyridine- $d_{5}$ ) spectrum of solanandaine (1) and solamargine (3) mixture. 


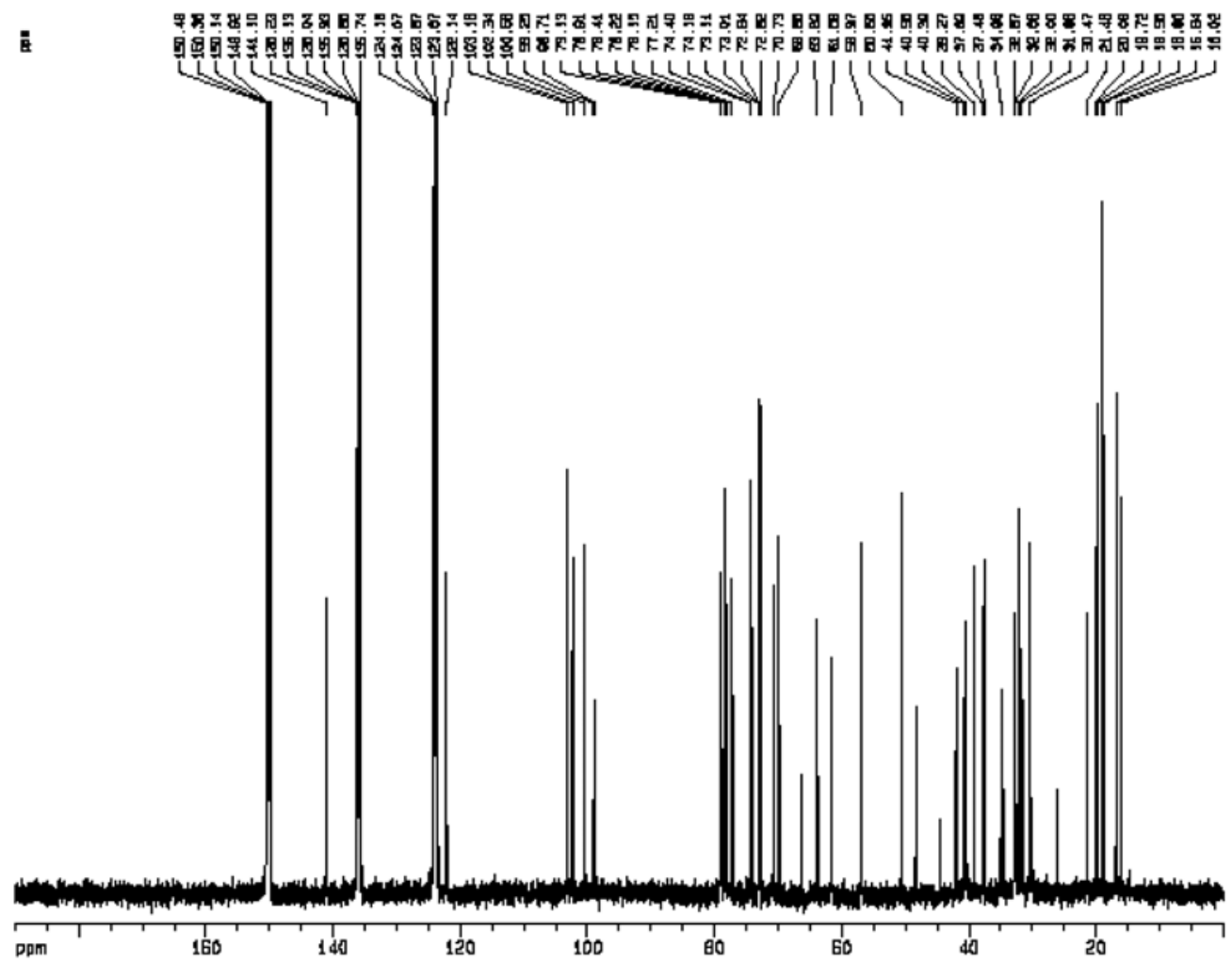

Figure S12. ${ }^{13} \mathrm{C}$ NMR (125 MHz, Pyridine- $d_{5}$ ) spectrum of solanandaine (1) and solamargine (3) mixture.
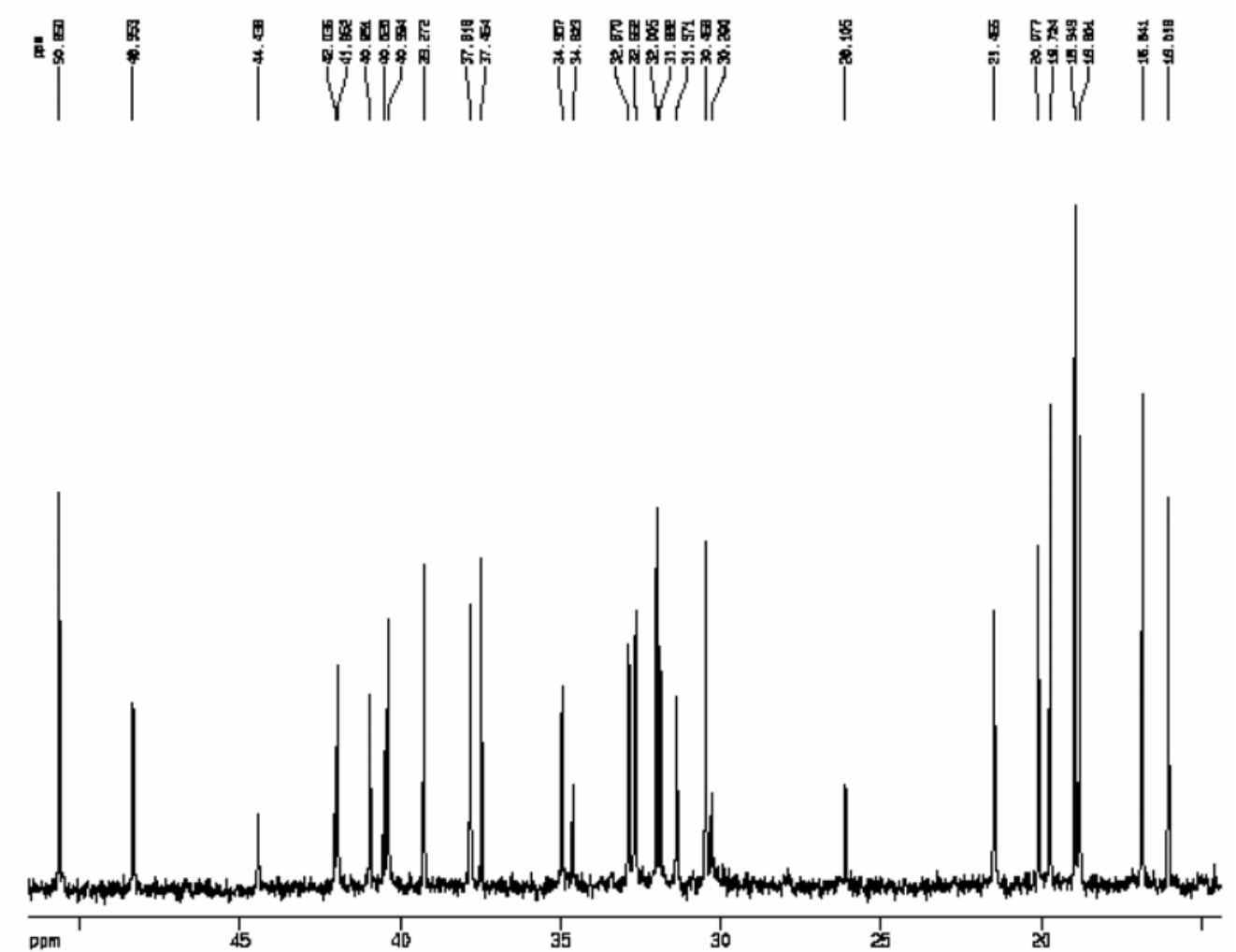

Figure S13. ${ }^{13} \mathrm{C}$ NMR spectrum $\left(125 \mathrm{MHz}\right.$, Pyridine- $\left.d_{5}\right)$ expansion upfield of solanandaine and solamargine mixture. 


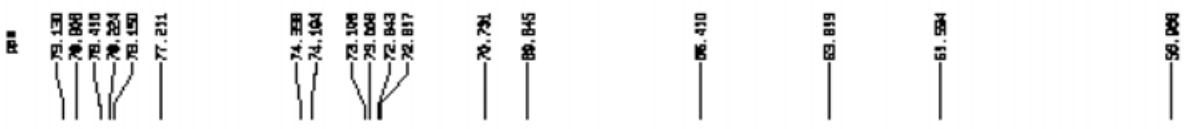

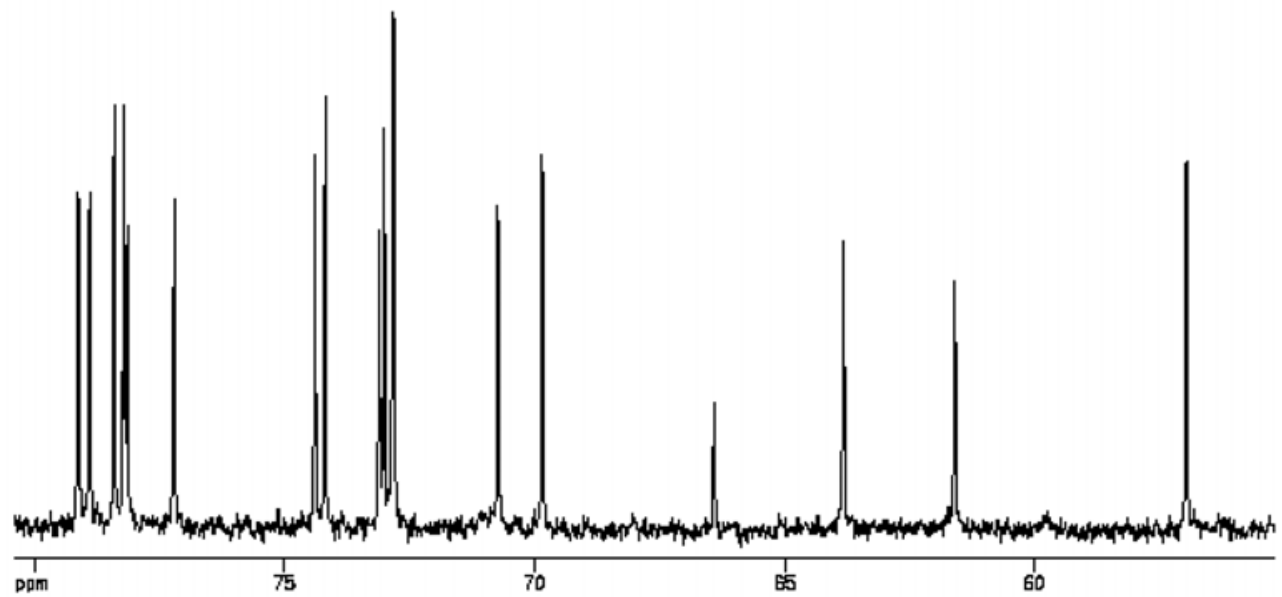

Figure S14. ${ }^{13} \mathrm{C}$ NMR spectrum (125 MHz, Pyridine- $d_{5}$ ) expansion downfield of solanandaine (1) and solamargine (3) mixture.

至
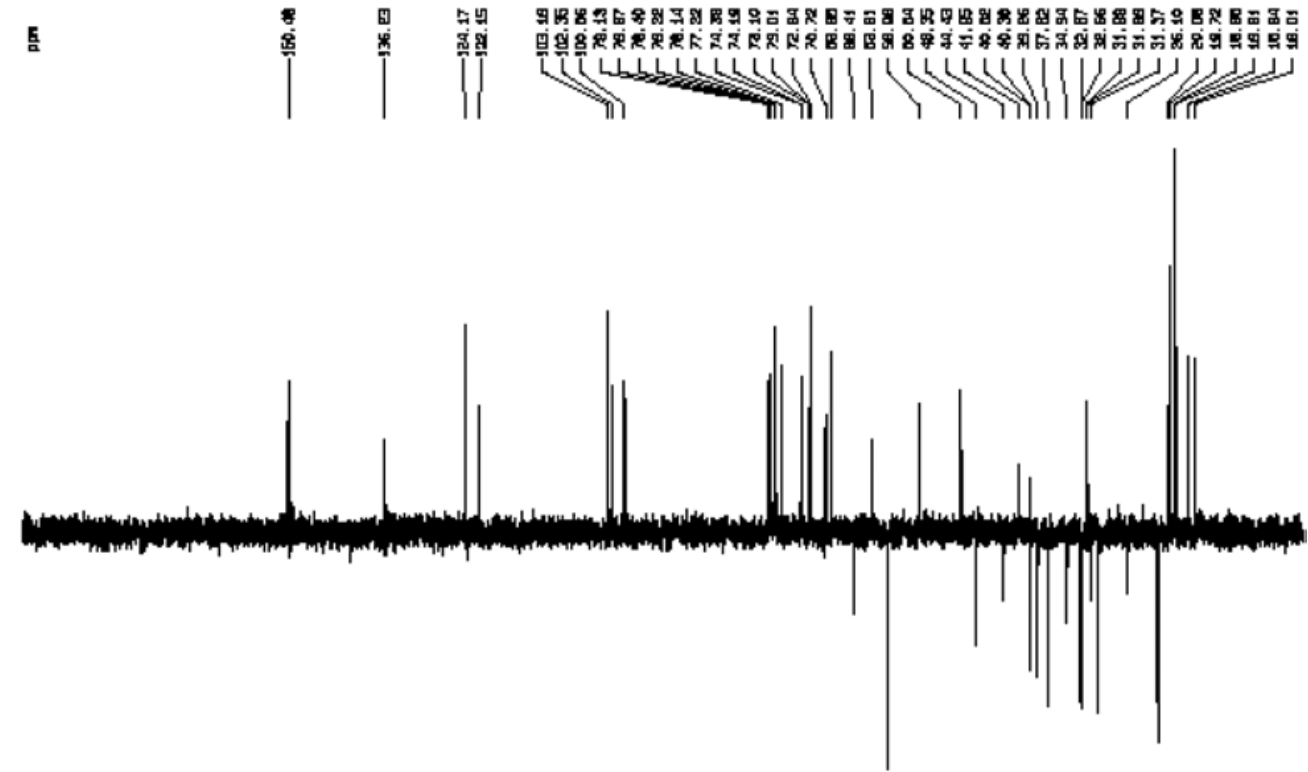

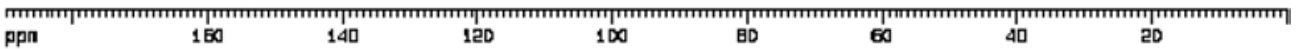

Figure S15. DEPT $\left(\theta=135^{\circ}, 125 \mathrm{MHz}\right.$, Pyridine- $\left.d_{5}\right)$ spectrum of solanandaine $(\mathbf{1})$ and solamargine $(\mathbf{3})$ mixture. 

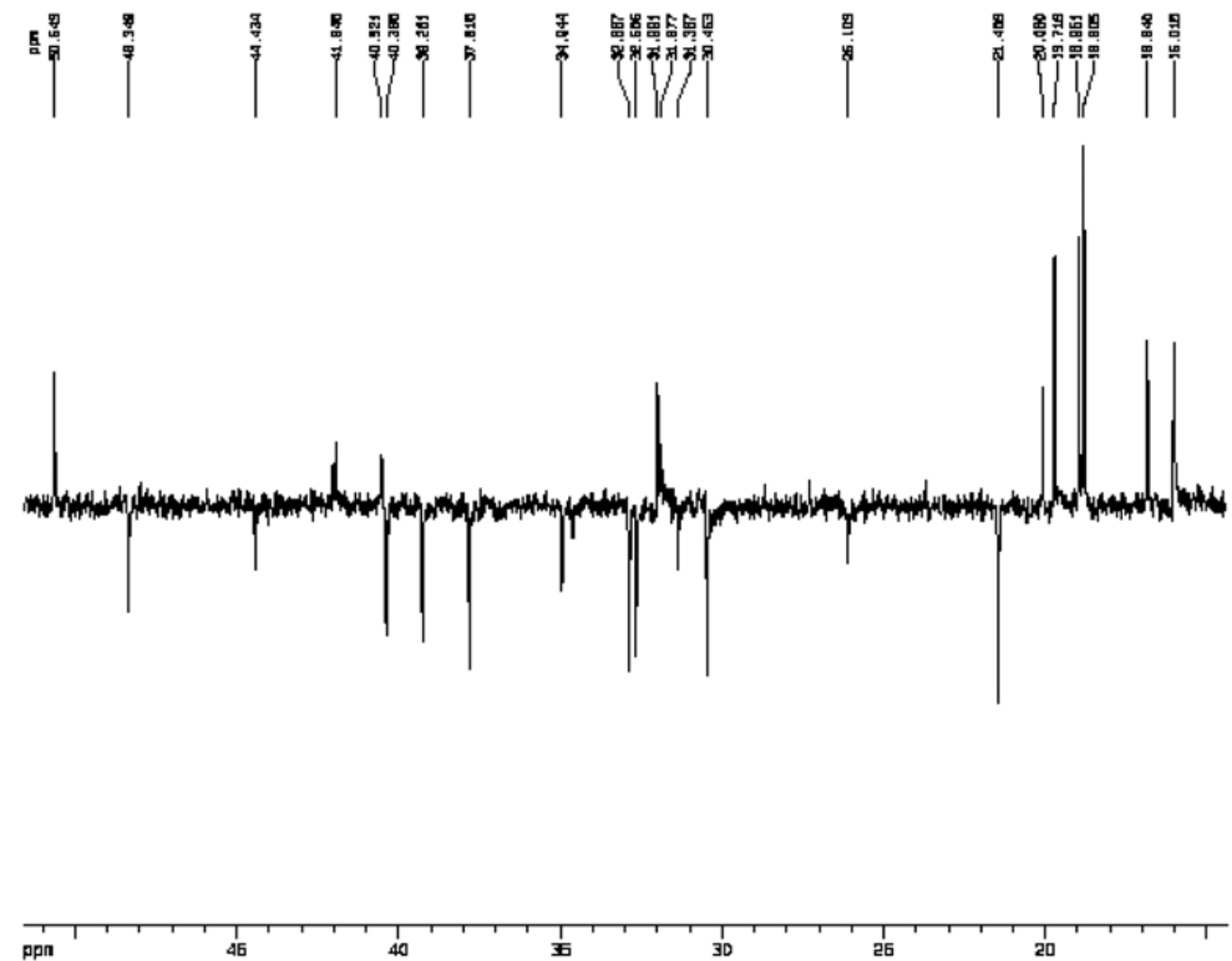

Figure S16. DEPT spectrum $\left(\theta=135^{\circ}, 125 \mathrm{MHz}\right.$, Pyridine- $\left.d_{5}\right)$ expansion upfield of solanandaine (1) and solamargine $(\mathbf{3})$ mixture.
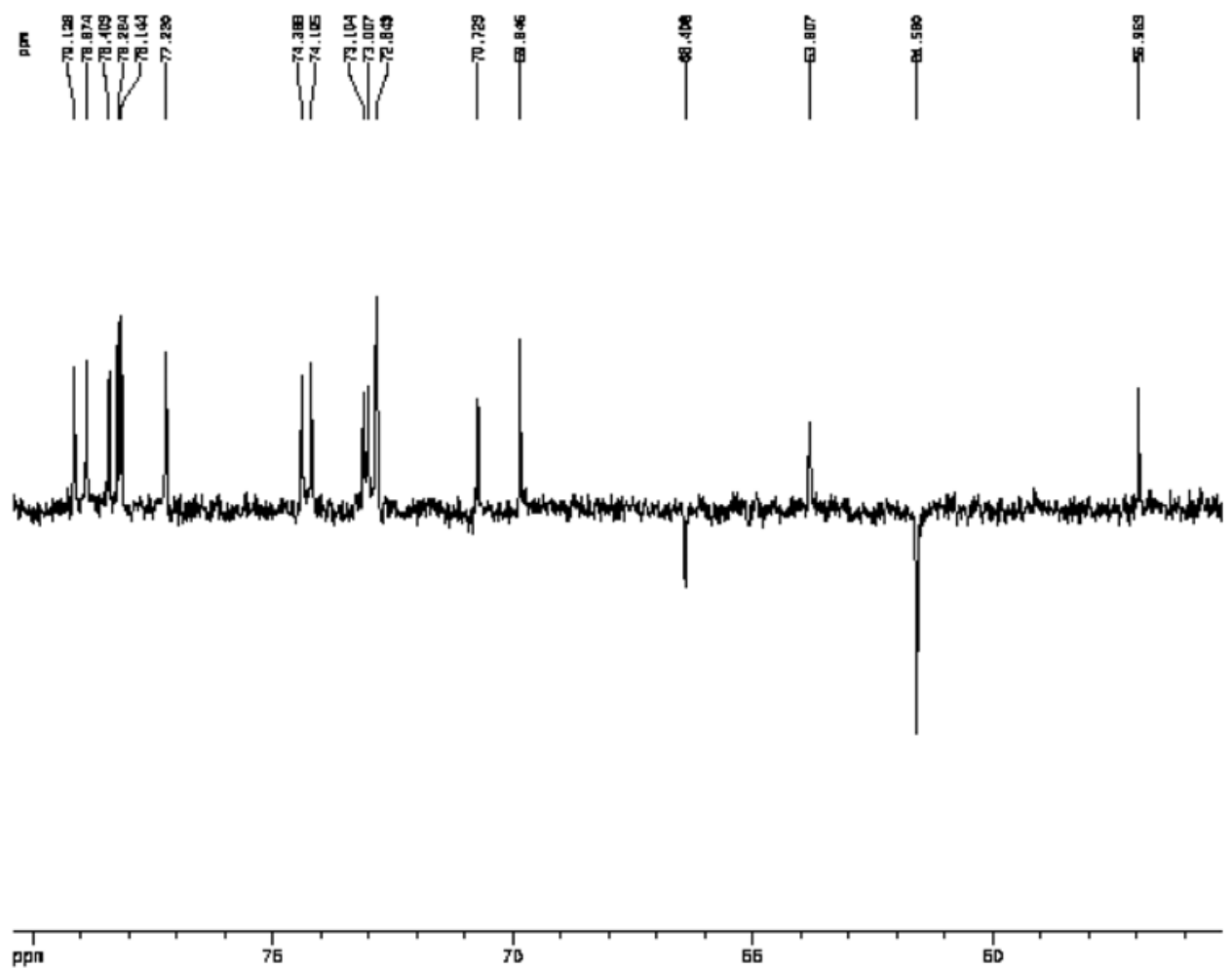

Figure S17. DEPT spectrum $\left(\theta=135^{\circ}, 125 \mathrm{MHz}\right.$, Pyridine- $\left.d_{5}\right)$ expansion downfield of solanandaine (1) and solamargine $(\mathbf{3})$ mixture. 


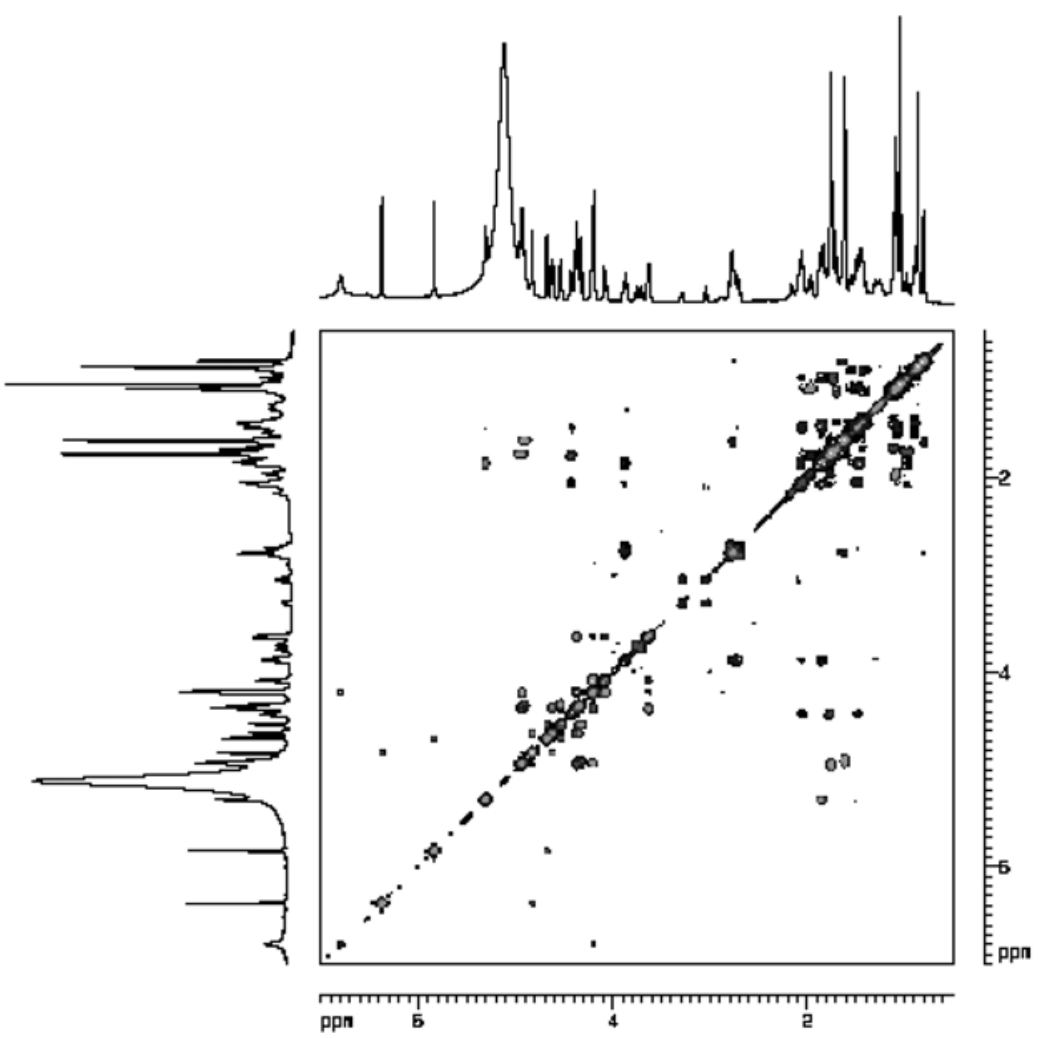

Figure S18. COSY spectrum ('H NMR: $500 \mathrm{MHz}$, Pyridine- $d_{5}$ ) of solanandaine (1) and solamargine (3) mixture.

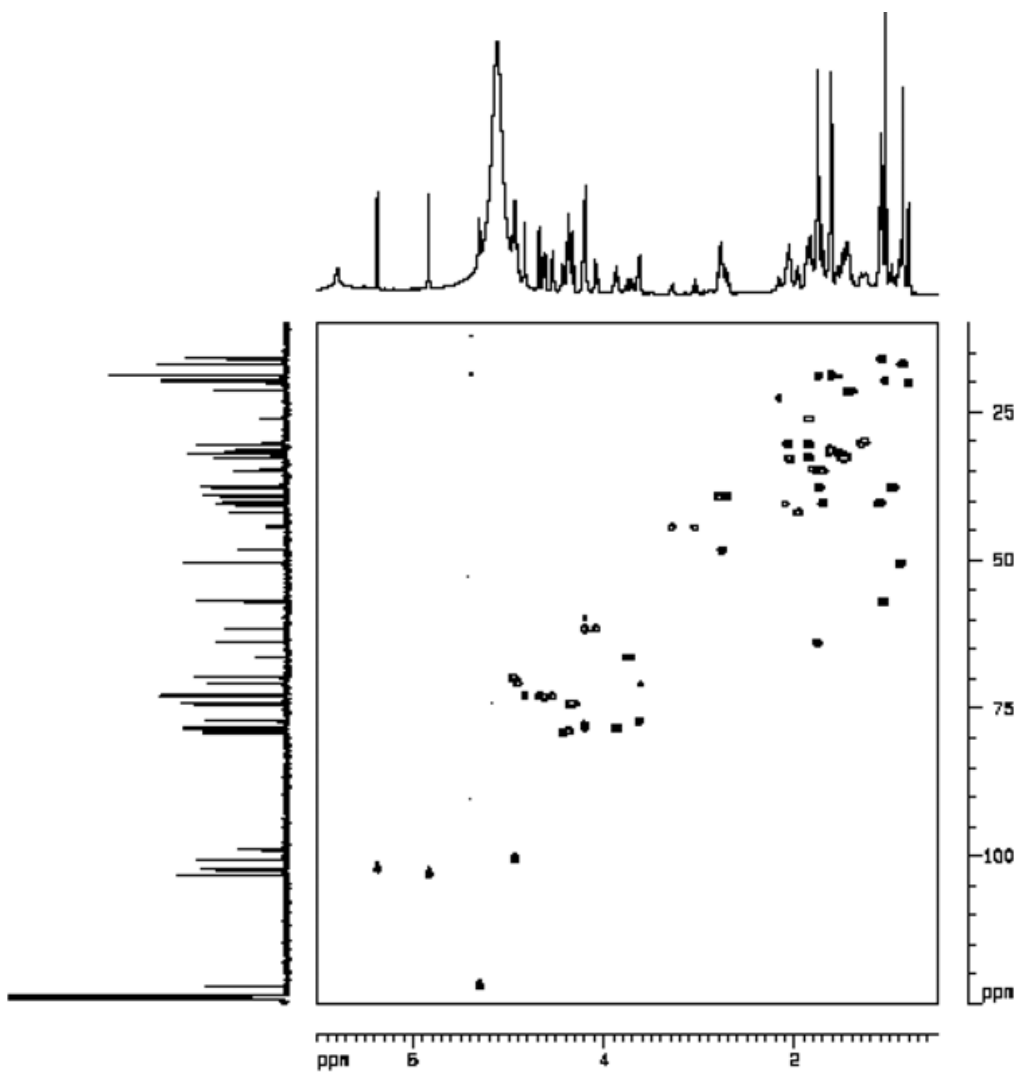

Figure S19. HSQC spectrum ( ${ }^{1} \mathrm{H}$ NMR: $500 \mathrm{MHz},{ }^{13} \mathrm{C}$ NMR: $125 \mathrm{MHz}$, Pyridine- $d_{5}$ ) of solanandaine $(\mathbf{1})$ and solamargine (3) mixture. 


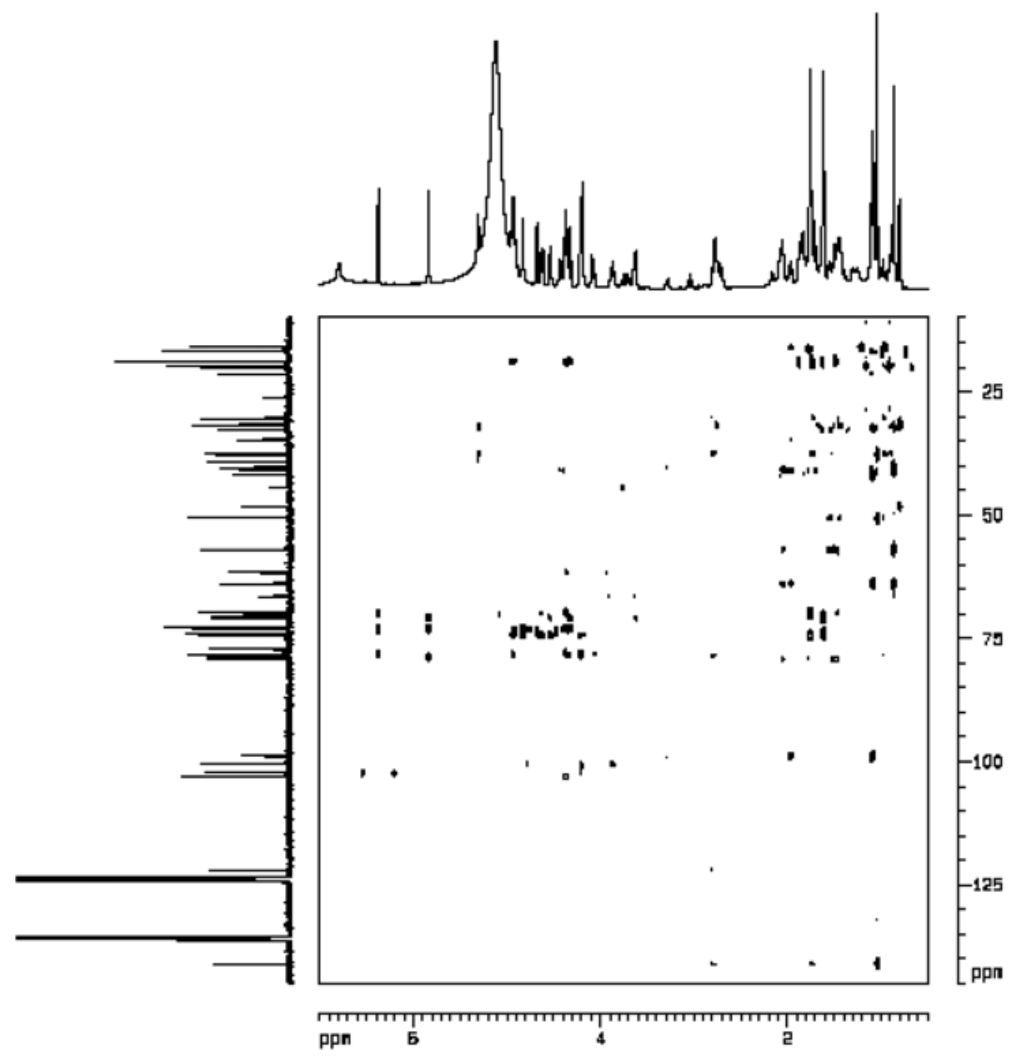

Figure S20. HMBC spectrum ( ${ }^{1} \mathrm{H}$ NMR: $500 \mathrm{MHz},{ }^{13} \mathrm{C}$ NMR: $125 \mathrm{MHz}$, Pyridine- $d_{5}$ ) of solanandaine (1) and solamargine (3) mixture.

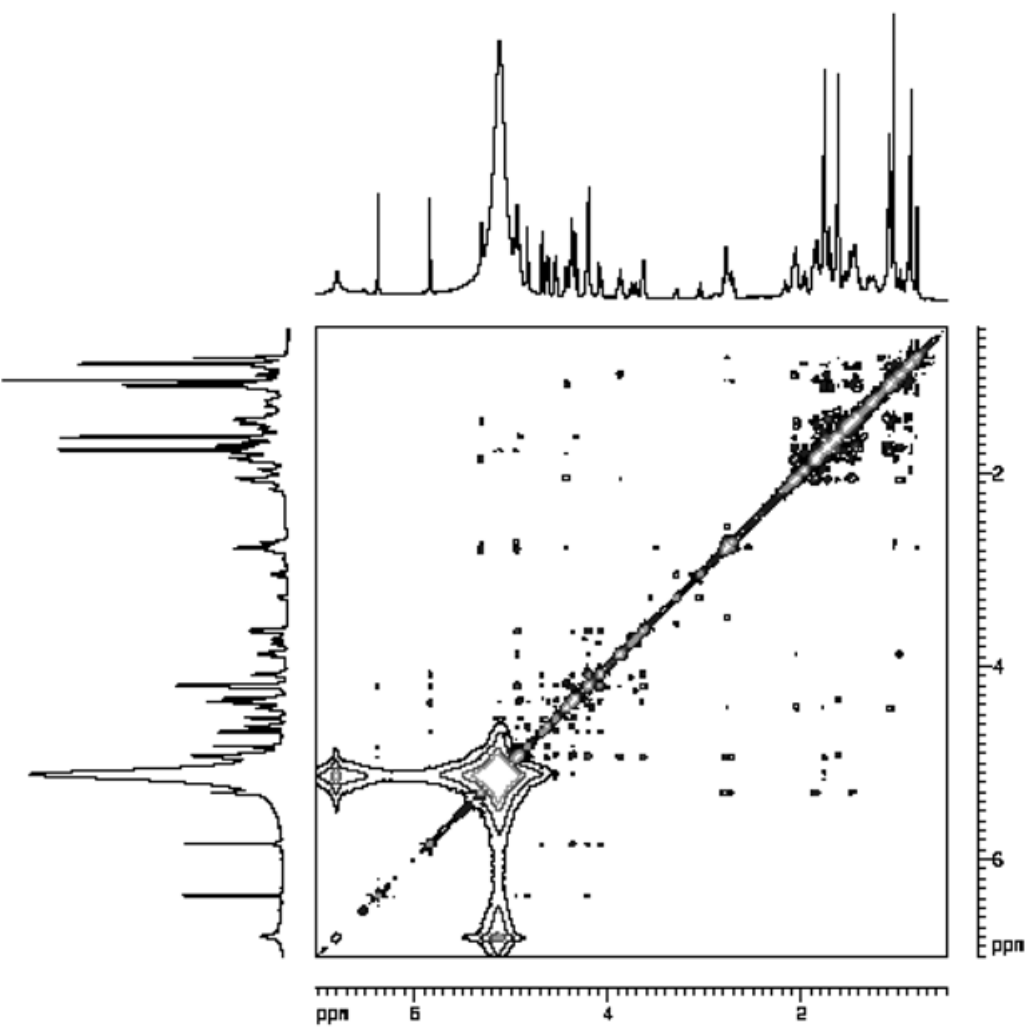

Figure S21. NOESY spectrum ( ${ }^{1} \mathrm{H}$ NMR: $500 \mathrm{MHz}$, Pyridine- $\left.d_{5}\right)$ of solanandaine $(1)$ and solamargine (3) mixture. 